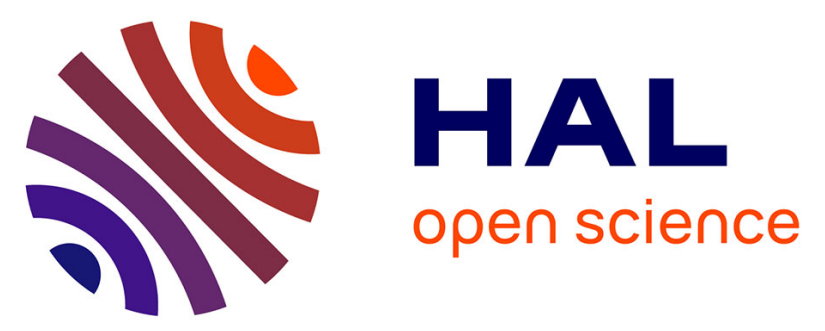

\title{
Holocene changes in vegetation composition in northern Europe: why quantitative pollen-based vegetation reconstructions matter
}

Laurent Marquer, Marie-José Gaillard, Shinya Sugita, Anna-Kari Trondman, Florence Mazier, Anne Birgitte Nielsen, Ralph Fyfe, Bent Vad Odgaard, Teija Alenius, H John B.Birks, et al.

\section{To cite this version:}

Laurent Marquer, Marie-José Gaillard, Shinya Sugita, Anna-Kari Trondman, Florence Mazier, et al. Holocene changes in vegetation composition in northern Europe: why quantitative pollenbased vegetation reconstructions matter. Quaternary Science Reviews, 2014, 90, pp.199-216. 10.1016/j.quascirev.2014.02.013 . hal-01174936

\section{HAL Id: hal-01174936 \\ https://hal.science/hal-01174936}

Submitted on 10 Jul 2015

HAL is a multi-disciplinary open access archive for the deposit and dissemination of scientific research documents, whether they are published or not. The documents may come from teaching and research institutions in France or abroad, or from public or private research centers.
L'archive ouverte pluridisciplinaire HAL, est destinée au dépôt et à la diffusion de documents scientifiques de niveau recherche, publiés ou non, émanant des établissements d'enseignement et de recherche français ou étrangers, des laboratoires publics ou privés. 


\title{
Holocene changes in vegetation composition in northern Europe: why quantitative pollen-based vegetation reconstructions matter
}

\author{
Laurent Marquer $^{\mathrm{a}, \mathrm{q}, *, 1}$, Marie-José Gaillard ${ }^{\mathrm{a}}$, Shinya Sugita ${ }^{\mathrm{b}}$, Anna-Kari Trondman ${ }^{\mathrm{a}}$, \\ Florence Mazier ${ }^{c}$, Anne Birgitte Nielsen ${ }^{\mathrm{d}}$, Ralph M. Fyfe ${ }^{\mathrm{e}}$, Bent Vad Odgaard ${ }^{\mathrm{f}}$, \\ Teija Aleniuss $^{\text {g, h }}$, H. John B. Birks ${ }^{\mathrm{i}, \mathrm{j}, \mathrm{k}}$, Anne E. Bjune ${ }^{\mathrm{i}}$, Jörg Christiansen ${ }^{1}$, John Dodson ${ }^{\mathrm{m}}$, \\ Kevin J. Edwards ${ }^{\mathrm{n}}$, Thomas Giesecke ${ }^{1}$, Ulrike Herzschuh ${ }^{\mathrm{o}}$, Mihkel Kangur ${ }^{\mathrm{b}}$, \\ Sebastian Lorenz ${ }^{\mathrm{p}}$, Anneli Poska ${ }^{\mathrm{q}}$, Manuela Schult ${ }^{\mathrm{p}}$, Heikki Seppä ${ }^{\mathrm{r}}$ \\ ${ }^{a}$ Department of Biology and Environmental Science, Linnaeus University, Sweden \\ ${ }^{\mathrm{b}}$ Institute of Ecology, Tallinn University, Estonia \\ ${ }^{\mathrm{c}}$ GEODE, UMR-CNRS 5602, Université de Toulouse Le Mirail, France \\ d Department of Geology, Lund University, Sweden \\ e School of Geography, Earth and Environmental Sciences, University of Plymouth, United Kingdom \\ ${ }_{\mathrm{f}}^{\mathrm{f}}$ Institute of Geoscience, Aarhus University, Denmark \\ ${ }^{g}$ Department of Philosophy, History, Culture and Art Studies, University of Helsinki, Finland \\ ${ }^{\mathrm{h}}$ Department of Archaeology, University of Turku, Finland \\ ${ }^{\mathrm{i}}$ Department of Biology and Bjerknes Centre for Climate Research, University of Bergen, Norway \\ ${ }^{\mathrm{j}}$ Environmental Change Research Centre, University College London, United Kingdom \\ ${ }^{\mathrm{k}}$ School of Geography and the Environment, University of Oxford, United Kingdom \\ ${ }^{1}$ Department of Palynology and Climate Dynamics, Albrecht-von-Haller-Institute for Plant Sciences, University of Göttingen, Germany \\ ${ }^{\mathrm{m}}$ Institute for Environmental Research, Australian Nuclear Science and Technology Organisation, Australia \\ ${ }^{\mathrm{n}}$ Departments of Geography \& Environment and Archaeology, School of Geosciences, University of Aberdeen, United Kingdom \\ ${ }^{\circ}$ Alfred-Wegener-Institut Potsdam and Institut für Geowissenschaften, Universität Potsdam, Germany \\ ${ }^{\mathrm{p}}$ Department of Geography and Geology, Ernst-Moritz-Arndt-University, Greifswald, Germany \\ ${ }^{\mathrm{q}}$ Department of Physical Geography and Ecosystem Science, Lund University, Sweden \\ ${ }^{\mathrm{r}}$ Department of Geosciences and Geography, University of Helsinki, Finland
}

\section{A R T I C L E I N F O}

\section{Article history:}

Received 23 August 2013

Received in revised form

10 February 2014

Accepted 13 February 2014

Available online

\section{Keywords:}

Holocene

Human impact

Northern Europe

Pollen

Quantitative regional plant abundance

Rate of compositional change

REVEALS (Regional Estimates of VEgetation

Abundance from Large Sites) model

Vegetation diversity indices

\begin{abstract}
A B S T R A C T
We present pollen-based reconstructions of the spatio-temporal dynamics of northern European regional vegetation abundance through the Holocene. We apply the Regional Estimates of VEgetation Abundance from Large Sites (REVEALS) model using fossil pollen records from eighteen sites within five modern biomes in the region. The eighteen sites are classified into four time-trajectory types on the basis of principal components analysis of both the REVEALS-based vegetation estimates (RVs) and the pollen percentage (PPs). The four trajectory types are more clearly separated for RVs than PPs. Further, the timing of major Holocene shifts, rates of compositional change, and diversity indices (turnover and evenness) differ between RVs and PPs. The differences are due to the reduction by REVEALS of biases in fossil pollen assemblages caused by different basin size, and inter-taxonomic differences in pollen productivity and dispersal properties. For example, in comparison to the PPs, the RVs show an earlier increase in Corylus and Ulmus in the early-Holocene and a more pronounced increase in grassland and deforested areas since the mid-Holocene. The results suggest that the influence of deforestation and agricultural activities on plant composition and abundance from Neolithic times was stronger than previously inferred from PPs. Relative to PPs, RVs show a more rapid compositional change, a largest decrease in turnover, and less variable evenness in most of northern Europe since $5200 \mathrm{cal}$ yr BP. All these changes are primarily related to the strong impact of human activities on the vegetation. This study demonstrates that RV-based estimates of diversity indices, timing of shifts, and rates of change in reconstructed vegetation provide new insights into the timing and magnitude of major human
\end{abstract}

\footnotetext{
* Corresponding author. Department of Biology and Environmental Science, Linnaeus University, Sweden.

E-mail addresses: laurent.marquer@lnu.se, laurent.marquer@nateko.lu.se (L. Marquer).

1 Current address: Department of Physical Geography and Ecosystem Science, Lund University, Sweden.
} 
disturbance on Holocene regional vegetation, features that are critical in the assessment of human impact on vegetation, land-cover, biodiversity, and climate in the past.

(c) 2014 Elsevier Ltd. All rights reserved.

\section{Introduction}

Fossil pollen records are the major source for reconstructing and understanding regional Holocene vegetation dynamics. However, various factors, such as inter-taxonomic differences in pollen productivity and dispersal, make pollen-vegetation relationships complex. As a result, estimation of plant abundances from pollen percentages is difficult (Sugita, 1994). Pollen-accumulation rates have been used to circumvent the interdependencies of percentage data and to assess vegetation change better (e.g. Giesecke and Fontana, 2008; Seppä et al., 2009), but vegetation reconstructions based on pollen-accumulation rates require robust and reliable chronologies and are dependent on differential pollen productivity and dispersal (e.g. Hicks, 2001; Sugita et al., 2010; Mazier et al., 2012b; Matthias and Giesecke, 2014). As an alternative, modern analogue techniques are widely used (e.g. Williams, 2002; Tarasov et al., 2007; Williams et al., 2011). One analogue approach is to use contemporary observations of forest cover from high-resolution radiometer sensors and provide reconstructions of forest cover. Such an approach is of limited use for non-analogue vegetation conditions. Using pollen counts and proportions, the Landscape Reconstruction Algorithm (LRA; Sugita, 2007a, 2007b) has been proposed for quantitative reconstructions of vegetation abundance at both regional and local spatial scales; the approach reduces biases caused by inter-taxonomic differences in pollen productivity and dispersal, differences in basin size, and spatial heterogeneity of vegetation. Moreover, the LRA is one of the few methods that corrects for the non-linear nature of the pollen-vegetation relationship using percentages and allows the reconstruction of past abundances of individual plant taxa around pollen sites.

Modern data-model comparisons using the first step of the LRA, the Regional Estimates of VEgetation Abundance from Large Sites (REVEALS) model (Sugita, 2007a) show that REVEALS-based estimates of vegetation abundance (RVs) are closer to the observed vegetation abundance than pollen percentages (PPs) (Sugita, 2007a; Hellman et al., 2008a). Gaillard et al. (1998), Broström et al. (1998), Sugita et al. (1998) and Hellman et al. (2009) demonstrated that herbaceous pollen taxa (non-arboreal pollen taxa, NAP) expressed in PPs tend to under-represent non-forested areas and that the NAP/vegetation relationship is not linear in southern Sweden; hence the magnitude of human impact inferred from NAP percentages is underestimated. At a European scale, REVEALS reconstructions (Sugita et al., 2008; Gaillard et al., 2010; Nielsen and Odgaard, 2010; Soepboer et al., 2010; Marquer, 2012; Nielsen et al., 2012; Fyfe et al., 2013; Trondman et al., personal communication) and other modelling approaches for estimating changes in the fraction of deforested land (Kaplan et al., 2009, 2011) suggest an under-estimation of deforested areas by PPs over the last three to six millennia. However, REVEALS-based analysis of regional changes in vegetation characteristics in northern Europe, such as composition (percentage cover of individual taxa or groups of taxa) and evenness, over the entire Holocene has not been attempted thus far.

To date, most studies of long-term changes in plant composition and floristic/vegetation/landscape diversity are based on PPs (e.g. Jacobson et al., 1987; Birks et al., 1988; Birks and Line, 1992; Grimm and Jacobson, 1992; Odgaard, 1994, 1999, 2001, 2007; Berglund et al., 2008; Birks and Birks, 2008). As RVs are different from PPs, our understanding is incomplete and in need of re-evaluation (Odgaard, 2001; Wang and Herzschuh, 2011; Fredh et al., 2012, 2013). Because of the restrictions involved in the selection of taxa for RV reconstruction, taxonomic richness is currently beyond the scope of the REVEALS approach. However, as most of the major taxa in the region are included in RVs, evenness of the REVEALSreconstructed vegetation is potentially informative for assessing some aspects of vegetation diversity at the regional spatial scale and provides new insights into past spatio-temporal dynamics of plant compositional change.

Anthropogenic impacts on the vegetation/landscapes of Europe have greatly affected biodiversity and plant composition in the Holocene. Palaeoecological studies in many parts of Europe suggest that Mesolithic hunter-gatherer populations had local and limited impacts on forests (Behre, 1988). Subsequent Neolithic and later populations enacted extensive forest clearance in order to establish farmland and to acquire wood for building and fuel (Behre, 1988). Recent geochemical and modelling studies have suggested that the onset of significant anthropogenic impacts through forest clearance in some areas started even earlier, perhaps as long as 8000 years ago (Ruddiman, 2003; Kaplan et al., 2011; Ruddiman et al., 2011). Estimates of the timing and magnitude of vegetation change using the REVEALS model are thus critical for further discussion of early anthropogenic impacts on the Earth system.

By using continuous time-series of RVs over the last 11,700 years in northern Europe, this study aims to assess:

1. how different RVs are from PPs for the entire Holocene in different regions;

2. the extent to which the timing of regional shifts in vegetation, rates of compositional change, and diversity (turnover and evenness) differ using RVs or PPs; and

3. the effects of human disturbance on long-term changes in vegetation abundance at regional and sub-continental scales.

\section{Target sites}

This study uses pollen records from eighteen target sites obtained from the European Pollen Database (Fyfe et al., 2009; Giesecke et al., 2014) or directly from the authors (Appendix Asupplementary data). They were selected using four criteria:

i) the sites should be representative of the five major modern biomes of northern Europe and distributed along transects from west (Ireland) to east (Estonia) and from north (Sweden/Finland) to south (Germany/Poland) (Fig. 1 and Appendix A-supplementary data). Sites located above $800 \mathrm{~m}$ a.s.l. were not considered because pollen dispersal and deposition in complex upland topographic contexts are not well understood yet; therefore, results obtained from high-elevation sites might be unreliable and not comparable with results from low and medium elevation sites. We use a map of potential modern biomes defined by the BIOME I model (Prentice et al., 1992, 1998) to assign sites to modern biomes.

ii) the sites should be 'large' lakes ( $\geq 50$ ha) because the REVEALS model (Sugita, 2007a) assumes that (1) there are no 


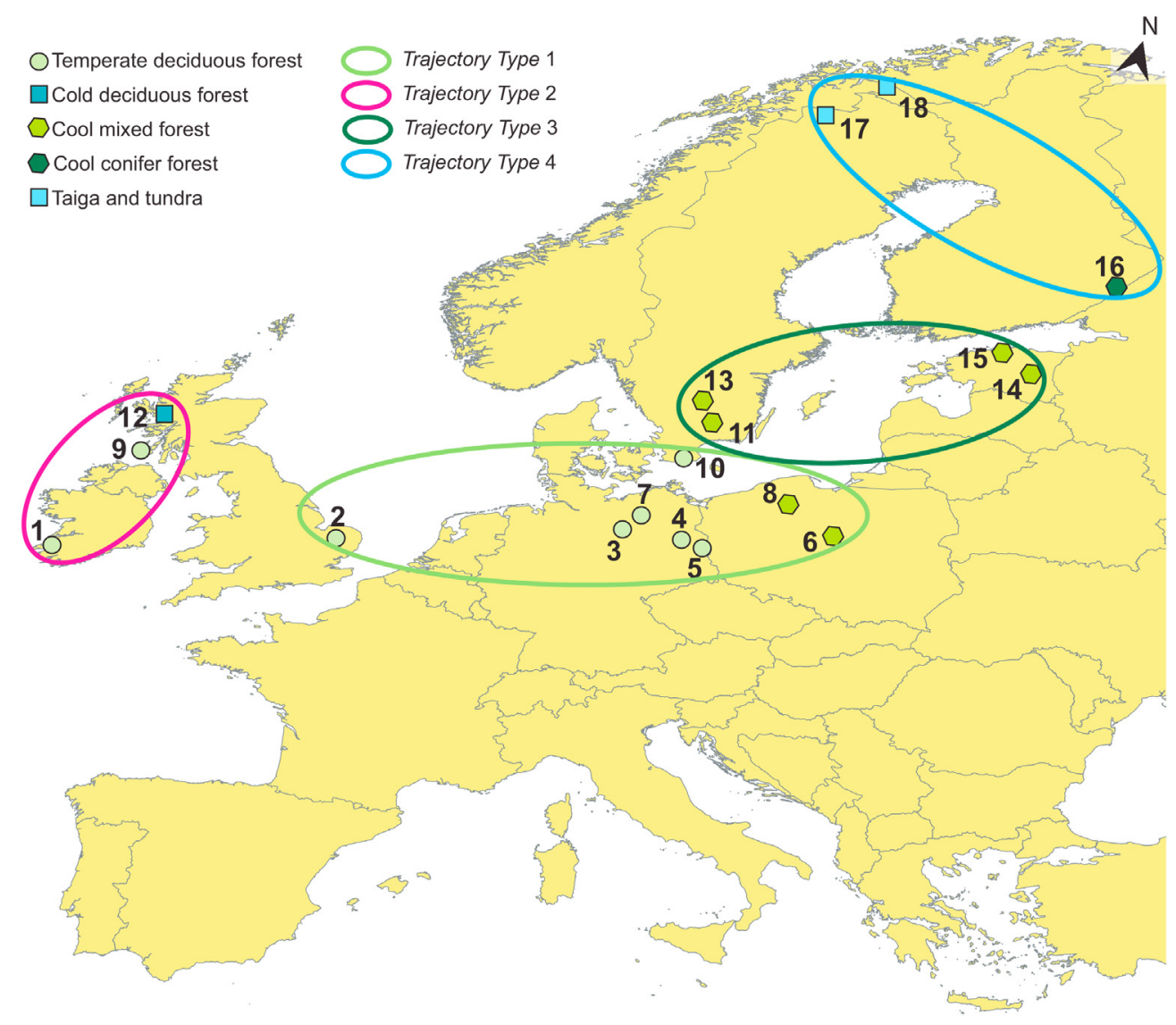

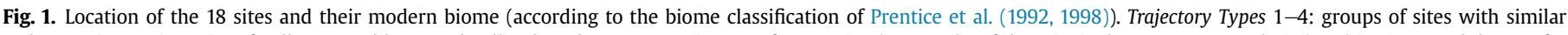

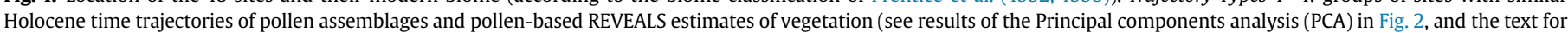
further explanation). REVEALS: “Regional Estimate of VEgetation Abundance from Large Sites", a model of pollen-vegetation relationship (Sugita, 2007a).

pollen-producing plants growing in the sedimentary basins, and thus lakes are more appropriate than mires for vegetation reconstruction; and (2) pollen records from 'large sites' represent regional vegetation (Janssen, 1981; Prentice, 1988; Sugita, 2007a; Hellman et al., 2008a, 2008b). Note that two sites are exceptions to that criteria; Großer Treppelsee (site 5) consists of three basins representing 67 ha in total, i.e. each basin is smaller than 50 ha; and Loch a'Bhogaidh (site 9) was a lake during the early- and mid-Holocene that became a mire during the late mid-Holocene.

iii) the pollen records should have a robust chronological control and a satisfactory time resolution of vegetation change for the entire Holocene (Appendixes A and B, supplementary data). All the chronologies are based on calibrated years BP (cal yr BP). If the original publications used uncalibrated radiocarbon dates, we established new chronologies in calibrated ages using the computer program Clam v2.0 (Blaauw, 2010).

iv) the pollen records from the selected sites should have high pollen counts per sample and as many samples as possible in each of the twenty-five time windows for which REVEALS was applied for reconstruction. We chose to use the following time windows: $0-100,100-350$, and 350700 cal yr BP and every 500-year interval between 700 and 11,700 cal yr BP. These time intervals were selected in order to obtain a reasonable compromise between (1) maximizing the time resolution over the late-Holocene, a period of rapid human-induced vegetation change, and (2) maximizing the size of pollen counts. The latter is important as simulations have demonstrated that the higher the pollen counts are, the smaller the error estimates of the RVs (Sugita, 2007a). The total pollen count in each time window at each site varies from 300 to 34,000 (the pollen counts for the youngest time windows are the lowest due to shorter time intervals).

\section{Methods}

\subsection{The REVEALS model}

REVEALS (Sugita, 2007a) is a generalised version of the $R$-value model proposed by Davis (1963). The $R$-value model deals with the non-linear nature of the pollen-vegetation relationship in percentages by reducing biases caused by inter-taxonomic differences in pollen productivity. REVEALS also reduces additional important biases caused by inter-taxon differences in pollen dispersal and deposition, and differences in the size of sedimentary basins. One of the important features of models for vegetation reconstruction, such as REVEALS, is that all the assumptions and parameter selection are explicit and transparent. Clear assumptions facilitate repeatable interpretation and robust assessment of the results. These assumptions also represent important working hypotheses that need to be tested; but testing these hypotheses is beyond the scope of this paper, and several of them have been tested elsewhere.

Important assumptions of the REVEALS model (Sugita, 2007a) include: (1) the source-distribution bias caused by heterogeneous distribution of the source plants (Sugita, 1994, 2013; Sugita et al., $2010)$ is negligible when pollen records from large sites $(\geq 50-$ 100 ha) are used; (2) most pollen comes from within a radius of 
$50-100 \mathrm{~km}$ of the site; and (3) if pollen from multiple sites within a region are used in a REVEALS reconstruction, there should be no spatial gradients in the vegetation composition of that region. Extensive simulations and several empirical studies show that these three assumptions are valid (Sugita, 2007a; Hellman et al., 2008a, 2008b; Soepboer et al., 2010). Additional assumptions include: 1) the sedimentary basin is a circular opening in the vegetation canopy; 2) wind is the sole agent of pollen transport; 3 ) pollen productivity estimates are taxon-specific and constant in space and time; 4) wind speed and atmospheric conditions are constant over the time of pollen dispersal; 5) pollen deposited on the water surface is well mixed before sedimentation, and the inter-taxon differences in pollen preservation in sediments are negligible. Effects of departure from those assumptions on the pollen dispersal/deposition models, as well as on REVEALS, have been discussed and evaluated elsewhere (e.g. Nielsen, 2004; Bunting and Middleton, 2005; Nielsen and Sugita, 2005; Sugita, 2007a; Gaillard et al., 2008; Mazier et al., 2008; Hellman et al., 2008a, 2008b). Additional assumptions (2), (4), and (5) are also used in traditional interpretation of pollen percentage records, although they have seldom been clearly specified. It is only when the resulting interpretations do not seem ecologically reasonable that investigators consider the possibility of departures from these assumptions.

\subsection{Parameter sets and pollen data for the REVEALS-based reconstructions}

The critical parameters for the REVEALS model include relative pollen productivity estimates (PPEs) and the fall speed of pollen of the constituent taxa (Table 1) (Sugita, 1993, 1994, 2007a). Other parameters are lake size (radius of the sedimentary basin), maximum spatial extent of the regional vegetation (distance from the centre of the site), wind speed, and other constants that are appropriate in neutral atmospheric conditions (Gaillard et al., 2008).

Broström et al. (2008) summarised methods used to obtain PPEs. PPEs were calculated from modern pollen data and related vegetation surveys in various regions in Europe, from northern Finland to the Jura mountains and the Swiss lowlands (Sugita et al., 1999; Broström et al., 2004, 2008; Nielsen, 2004; Bunting et al., 2005; Nielsen and Sugita, 2005; Räsänen et al., 2007; Soepboer et al., 2007; Mazier et al., 2008; von Stedingk et al., 2008; Poska et al., 2011; Abraham and Kozakova, 2012; Hjelle and Sugita, 2012; Matthias et al., 2012). Various physical and biological factors, such as climate, soil, topography, genetic variation, plant age, and anthropogenic impacts are likely to affect pollen productivity (e.g. Broström et al., 2008). In this study we adopt the "Standard 2" set of PPEs and their error estimates from the LANDCLIM (LAND cover - CLIMate interactions in NW Europe during the Holocene) project (Gaillard et al., 2010; Mazier et al., 2012a); this set represents the first PPEs based on a synthesis of all values available in the study region for 25 taxa (Table 1). "Standard 2" set includes taxonspecific mean PPEs and their standard errors calculated according to the following rules: (i) when 5 or more PPEs were available for a pollen type $(N \geq 5)$, the largest and the smallest estimates (generally outlier values) were excluded, and the mean was calculated using the remaining estimates; (ii) when $N=4$, the most extreme value was excluded, and the mean was calculated using the remaining three values; and (iii), when $N \leq 3$, the mean was based on all values available. This set of PPEs is used for all studies within the LANDCLIM project so far (Nielsen et al., 2012; Fyfe et al., 2013; Trondman et al., submitted for publication). The modern radius of the sedimentary basin, calculated from its total area, is assumed to be constant through time for all target sites.
Table 1

Relative pollen productivity estimates (PPEs) and fall speeds of pollen for the 25 taxa used in the REVEALS analyses. The PPEs of all taxa are relative to a reference taxon, in this case Gramineae (PPE = 1). Note that the Plantago montana-type includes the species Plantago montana, P. alpina, and P. maritima.

\begin{tabular}{|c|c|c|c|}
\hline $\begin{array}{l}\text { Plant taxa/pollen } \\
\text { morphological types }\end{array}$ & $\begin{array}{l}\text { Abbreviations } \\
\text { used in figures }\end{array}$ & $\begin{array}{l}\text { PPEs and their } \\
\text { standard errors }\end{array}$ & $\begin{array}{l}\text { Fall speeds } \\
\text { of pollen }(\mathrm{m} / \mathrm{s})\end{array}$ \\
\hline \multicolumn{4}{|l|}{ Trees and tall shrubs } \\
\hline Abies & Abi. & $6.88 \pm 1.44$ & 0.12 \\
\hline Alnus & Alnu. & $9.07 \pm 0.1$ & 0.021 \\
\hline Betula & Betu. & $3.09 \pm 0.27$ & 0.024 \\
\hline Carpinus & Carp. & $3.55 \pm 0.43$ & 0.042 \\
\hline Corylus & Cory. & $1.99 \pm 0.19$ & 0.025 \\
\hline Fagus & Fagu. & $2.35 \pm 0.11$ & 0.057 \\
\hline Fraxinus & Fraxi. & $1.03 \pm 0.11$ & 0.022 \\
\hline Juniperus & Juni. & $2.07 \pm 0.04$ & 0.016 \\
\hline Picea & Pice. & $2.62 \pm 0.12$ & 0.056 \\
\hline Pinus & Pinu. & $6.38 \pm 0.45$ & 0.031 \\
\hline Quercus & Quer. & $5.83 \pm 0.15$ & 0.035 \\
\hline Salix & Sali. & $1.22 \pm 0.11$ & 0.022 \\
\hline Tilia & Tili. & $0.8 \pm 0.03$ & 0.032 \\
\hline Ulmus & Ulmu. & $1.27 \pm 0.05$ & 0.032 \\
\hline \multicolumn{4}{|l|}{ Dwarf shrubs } \\
\hline \multicolumn{4}{|l|}{ Herbs } \\
\hline Artemisia & Arte. & $3.48 \pm 0.2$ & 0.025 \\
\hline Cerealia-t & Cere. & $1.85 \pm 0.38$ & 0.06 \\
\hline Cyperaceae & Cype. & $0.87 \pm 0.06$ & 0.035 \\
\hline Filipendula & Fili. & $2.81 \pm 0.43$ & 0.006 \\
\hline Gramineae & Gram. & $1 \pm 0$ & 0.035 \\
\hline Plantago lanceolata & Pl.lan. & $1.04 \pm 0.09$ & 0.029 \\
\hline Plantago media & Pl.med. & $1.27 \pm 0.18$ & 0.024 \\
\hline Plantago montana & Pl.mt. & $0.74 \pm 0.13$ & 0.03 \\
\hline Rumex acetosa-t & Ru.ac. & $2.14 \pm 0.28$ & 0.018 \\
\hline Secale-t & Seca-t & $3.02 \pm 0.05$ & 0.06 \\
\hline
\end{tabular}

Atmospheric conditions during pollen dispersal are assumed to be neutral, and the wind speed is set to $3 \mathrm{~m} / \mathrm{s}$, following earlier studies (e.g. Hellman, 2008a,b; Sugita et al., 2008). The maximum spatial extent of the regional vegetation from the centre of the lake basin is defined as $50 \mathrm{~km}$ for all target sites, because we expect that at least $80 \%$ of the pollen of the constituent taxa (Table 1) to come from within this distance (Hellman et al., 2008a). Therefore, the output from the REVEALS model represents vegetation abundance as proportions of cover (or percentage cover) for individual plant taxa (25) within a $50 \mathrm{~km}$ radius area from the centre of each lake basin. Standard errors for the RVs are calculated following the method of Sugita (2007a).

\subsection{Numerical techniques}

We use several multivariate methods to summarise and classify the spatio-temporal patterns of the RVs and PPs. The RV and PP results are analysed separately, following the same protocol:

(1) Classification of the time trajectories of regional taxa compositional change at individual sites: Principal components analysis (PCA) is used to characterise the time trajectories over the last 11,700 years. The gradient lengths determined by detrended correspondence analysis are short $(<2.2$ standard deviations of compositional turnover) for both the RV and PP results based on the 18 sites and 25 taxa. Accordingly, linear-based models such as PCA are appropriate for data analysis (ter Braak and Prentice, 1988). All the calculations are implemented using CANOCO 4.5 for Windows (ter Braak and Šmilauer, 2002). Before running PCA, the threshold value of $1 \%$ (PPs and RVs separately) is used to determine the start (age) of the regular presence of individual taxa at individual target sites; for each taxon, pollen 
occurring prior to its "start age" are excluded from the analysis. This procedure is adopted to reduce the influence of rare pollen types on the PCA results during the early- and mid-Holocene. The RV and PP results are then transformed using the arcsine square-root transformation to extend the range of the results and to compress the centre of their distribution (McCune and Grace, 2002); this transformation tends to stabilise variances. The site PCA trajectories are then grouped into "Trajectory Types" by visual inspection. PCA results - axes 1 and 2 - are plotted as a distance biplot using CanoDraw 4 for Windows (ter Braak and Šmilauer, 2002).

(2) Timing of Holocene regional taxa compositional changes: For each Trajectory Type, mean RVs and mean PPs of individual taxa are calculated for each of the 25 time windows. We then use CONISS, a temporally constrained incremental sum-of-squares cluster analysis (Grimm, 1987; as implemented in TILIA V.1.7.16), to identify the timing of marked changes in regional taxa composition for each Trajectory Type. Square-root transformation is applied to the RV and PP results and the Edwards and Cavalli-Sforza's chord distance (commonly used in TILIA) is used as the dissimilarity coefficient in CONISS. TG View V.2.0.2 is used to plot the dendrograms.

(3) Differences between PP- and RV-based results: The "Holocene dissimilarity" is calculated for each taxon $i$ and for each Trajectory Type, defined as the dissimilarity of taxon $i=\sum_{1}^{25}\left|\mathrm{PP}_{i}-\mathrm{RV}_{i}\right|$ (summed for all 25 time windows). This measure identifies plant taxa that show significant differences between RVs and PPs for each Trajectory Type over the entire Holocene. The squared chord distance (Prentice, 1980) is calculated to evaluate the dissimilarities between RVs and PPs for each Trajectory Type, when all taxa are considered together. In this case, squared chord distance is preferred over Euclidean distance because it gives greater weight to taxa that have lower abundances, whereas Euclidean distance is strongly influenced by taxa with high abundances (Prentice, 1980).

(4) Rate of regional taxa compositional change, turnover, and evenness: The following measures are calculated using both the PP- and RV-based results: A) The rate of taxa compositional change (sensu Grimm and Jacobson, 1992) reveals periods of stability and change for PPs and RVs. It is calculated as the dissimilarity coefficient (squared chord distance) between two adjacent time windows divided by the time interval between them. B) Turnover is defined as the rate or magnitude of change in taxa composition along pre-defined spatial or environmental gradients (Vellend, 2001). The calculation of turnover is based on detrended canonical correspondence analysis (DCCA) using CANOCO (Lepš and Šmilauer, 2003; Birks, 2007; Birks and Birks, 2008). An arcsine square-root transformation of both RVs and PPs is applied. Ordination is constrained by sample age and detrended by segments. The sample scores (gradient length expressed in standard deviation units of compositional turnover) represent compositional change; when plotted along the time-constrained DCCA axis 1, the scores correspond to the compositional change along a predefined major gradient (in this case, time), and can be considered as the regional taxa compositional turnover. C) Evenness refers to how numerically equal the taxa (in this case the 25 dominant pollen taxa) are in their abundances (Magurran, 2004). Below we refer to "RV and PP evenness", i.e. regional vegetation evenness (based on RVs) and pollen percentage evenness (based on PPs), rather than floristic evenness, which, by definition involves all species present in the vegetation or the pollen assemblages. The evenness index used here for RVs and PPs is the Shannon's equitability (EH) following Odgaard (2007) and also used in Fredh et al. (2012, 2013). It is the ratio between the Shannon index $(H)$ and the maximum possible Shannon index $\left(H_{\max }\right)$ (e.g. Rosenzweig, 1995)

$$
E H=H / H_{\max }=-\sum_{i=1}^{q} P_{i} \log P_{i} / \log q
$$

where $P_{i}$ is the proportion of taxon $i$ and $q$ is the number of dominant taxa. $H_{\max }$ represents the maximum equitability of the dominant taxa present, i.e. each taxon is represented by an equal proportion. Shannon's equitability varies between 0 and 1 , with 1 being complete evenness.

\section{Results}

\subsection{Trajectory Types}

The PCA results indicate that four Trajectory Types can be separated for both RVs (Fig. 2) and PPs (Fig. 3). Those Trajectory Types roughly correspond to modern biomes (see Section 2). They also show that some of the target sites are in ecotonal locations between different biomes, and that their biome characteristics may have changed over the Holocene. Each of the four Trajectory Types comprises the trajectories of several pollen records, as follows:

- Trajectory Type 1: this is characterised by sites located in the modern 'temperate deciduous forest' biome (Germany: sites 3, 4, 5 and 7, England: site 2; southern Sweden: site 10). Sites 6 and 8 (in Poland), located in the modern 'cool mixed forest' biome, are also included in this Trajectory Type, which indicates that those sites have changed from vegetation types resembling the modern 'temperate deciduous forest' biome to vegetation types characteristic of the modern 'cool mixed forest' biome through the Holocene. Note that vegetation characteristics for sites 1 and 9 have also changed from the modern 'temperate deciduous forest' biome to the 'cold deciduous forest' biome through the Holocene (see Trajectory Type 2). The individual trajectories of sites within type 1 run from the upper left quadrant of the PCA biplot, through the lower right quadrant, to the upper right or left quadrants (Fig. 2). These trajectories are strongly associated with Juniperus, Pinus, Betula, and Gramineae (we use the family name Gramineae instead of Poaceae as in Flora Europaea) at the beginning of the Holocene, with deciduous trees (Tilia, Ulmus, Alnus, Corylus, Fraxinus, Quercus) during the mid-Holocene, and in the late-Holocene, initially with Abies, Fagus, and Carpinus, and later with arable indicators, in particular Cerealia-t and Secale-t.

- Trajectory Type 2: this is characterised by the Scottish and Irish sites $(1,9,12)$ that are located in the modern 'temperate deciduous forest' and 'cold deciduous forest' biomes. These trajectories are concentrated in the upper half of the PCA biplot close to axis 2 (positive or negative). Overall, this Trajectory Type is strongly associated with Cyperaceae, Gramineae, Carpinus, and Calluna during the late-Holocene.

- Trajectory Type 3: this is characterised by sites located in the modern 'cool mixed forest' biome (i.e. Sweden: sites 11 and 13; Estonia: sites 14 and 15). These trajectories move from the upper left quadrant of the PCA biplot to the lower left quadrant, then to the lower right quadrant, and back to the lower left quadrant. Like Trajectory Type 1, it is strongly associated with 

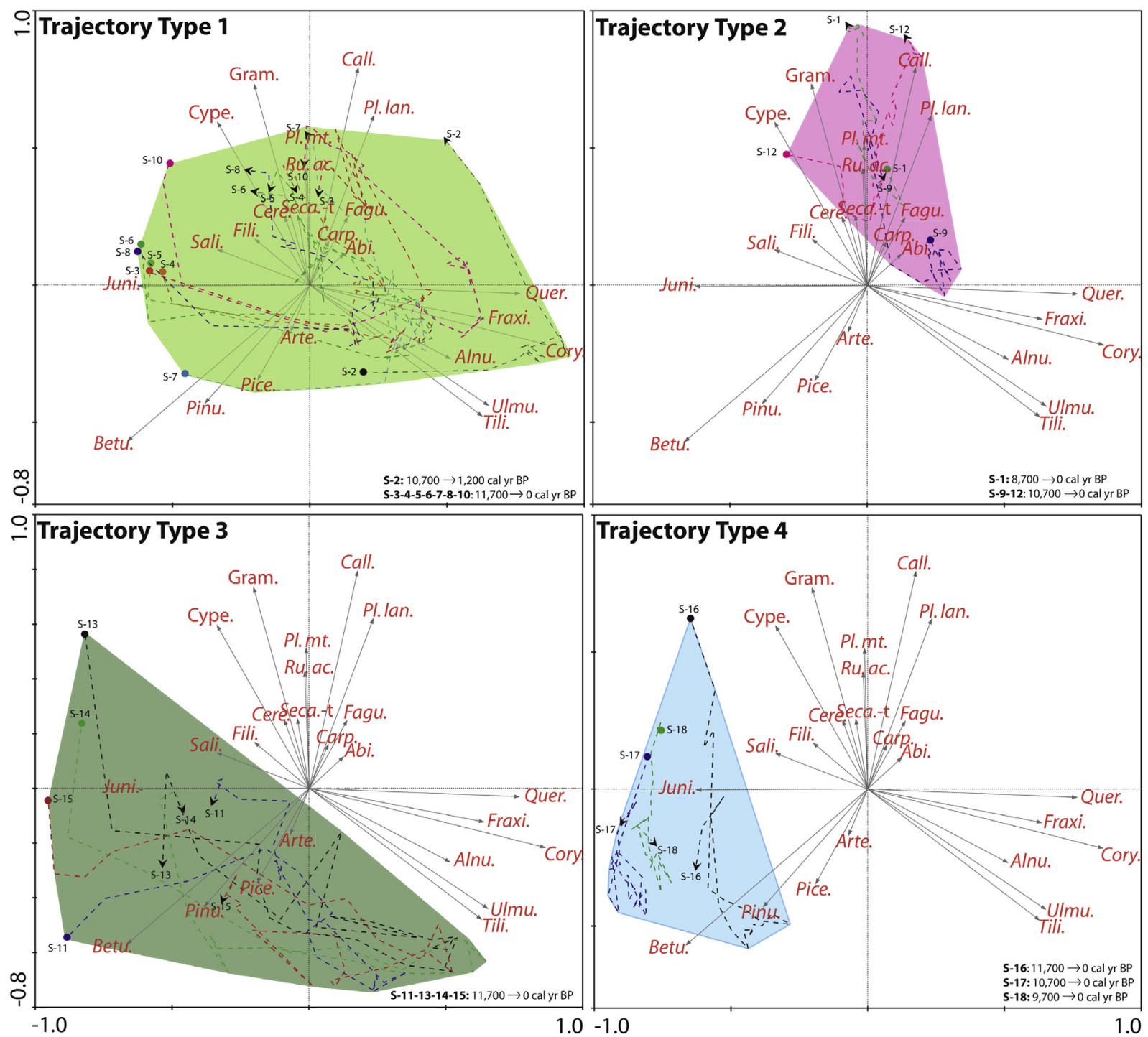

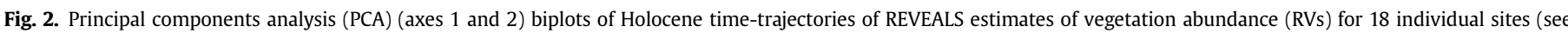

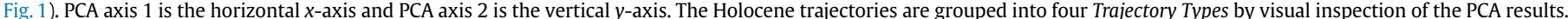

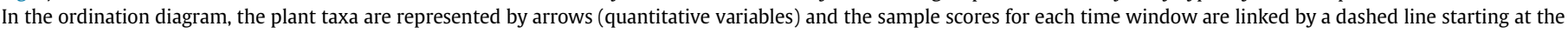

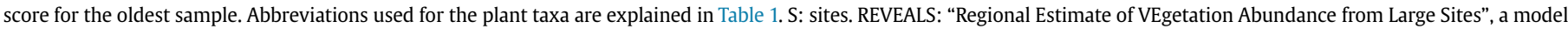
of pollen-vegetation relationship (Sugita, 2007a).

Juniperus, Pinus, Betula, and Gramineae at the beginning of the Holocene, and mainly with deciduous trees (Corylus, Ulmus, Tilia, Alnus) during the mid-Holocene, but it differs from Trajectory Type 1 during the late-Holocene in being associated with Picea, and, to a lesser extent, with Gramineae and indicators of arable land.

- Trajectory Type 4: This is characterised by sites located in the modern 'taiga and tundra' biome (northern Sweden and Finland: sites 17 and 18). Site 16 (southern Finland, modern 'cool conifer forest' biome), is also included in this Trajectory Type, which indicates that its vegetation characteristics changed from the modern 'taiga and tundra' biome to the 'cool conifer forest' biome through the Holocene. The trajectories are concentrated in the left half of the PCA biplot along axis 2 where the PCA scores are either positive or negative; the scores along axis 1 are highly negative. Overall, this Trajectory Type is strongly associated with Betula, Pinus, Juniperus, and Salix throughout the Holocene, with an increasing influence of Picea over time.
4.2. Differences in regional taxa abundance between PP- and RVbased results

Differences in the PCA biplots (axes 1 and 2) based on RVs and PPs for the Trajectory Types are summarised in Fig. 3. Trajectory Types are better separated when RVs rather than PPs are used. This is due to the different influence of the pollen taxa (quantitative variables) between the PP-based and the RV-based PCA results; the latter being largely a consequence of the use of PPEs in the REVEALS model to correct the biases of PPs due to inter-taxon differences in pollen productivity and dispersal. For example, the PPs of Pinus (high PPEs, Table 1, i.e. a taxon overrepresented in PPs) are higher than its RVs over the entire study area (Fig. 4) and exert a stronger numerical influence (as shown by its long taxon vector) on the PP-based than on the RVbased PCA results (Fig. 3). It is the opposite for Gramineae (low PPE, under-represented in PPs (Fig. 4)). Moreover, Trajectory Types differ in the taxa which are most responsible for the dissimilarities between the RV- and PP-based PCA results. The main 

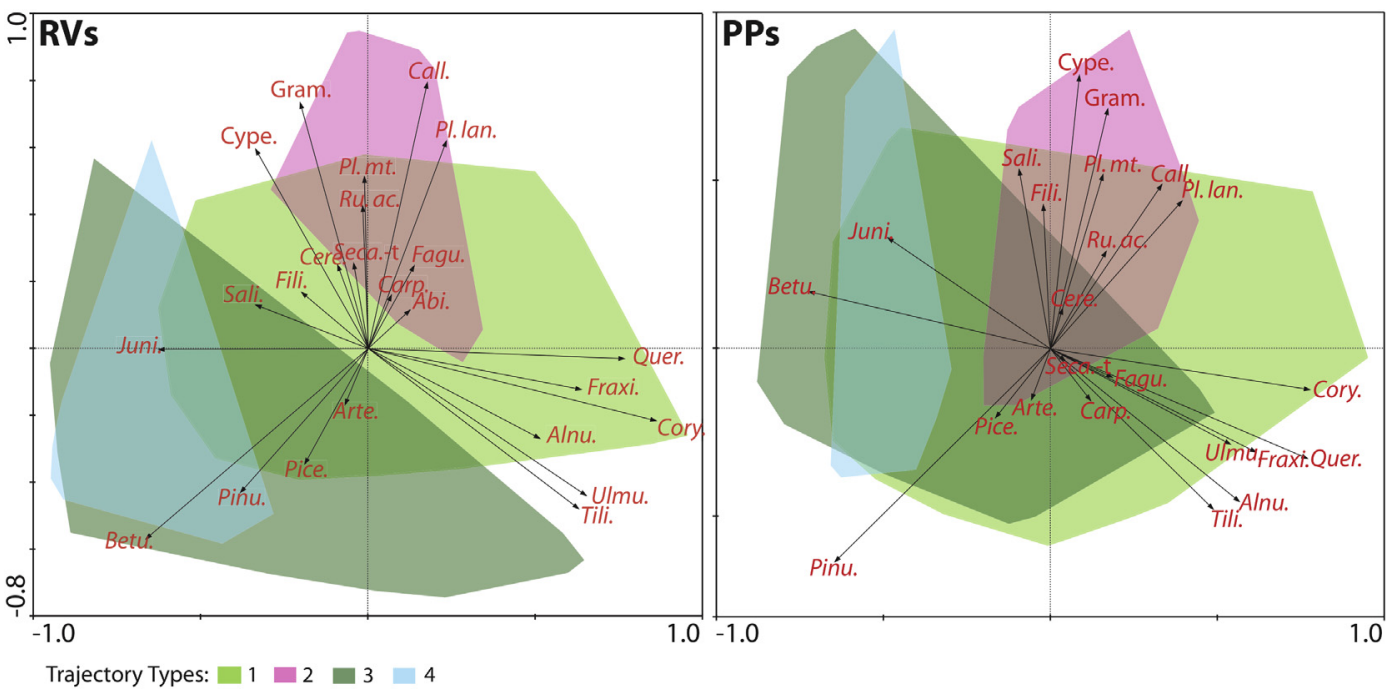

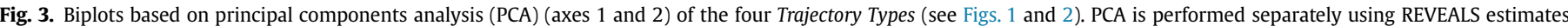

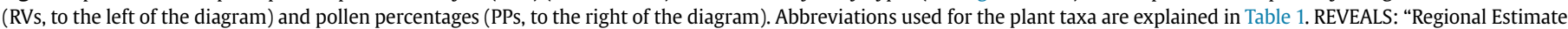

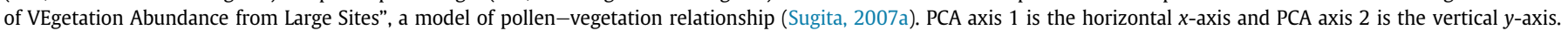
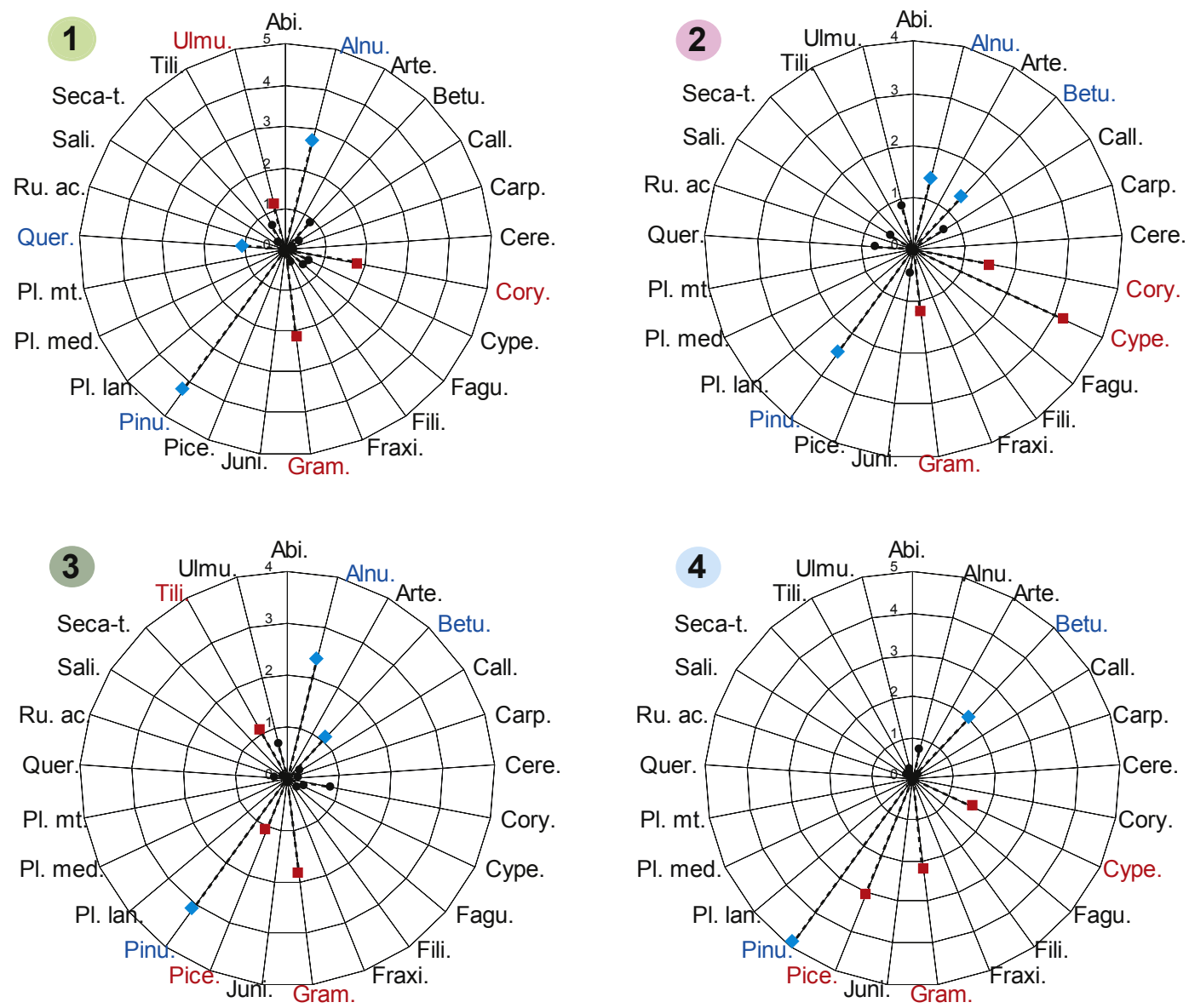

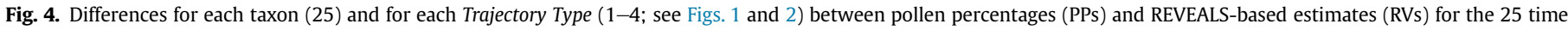

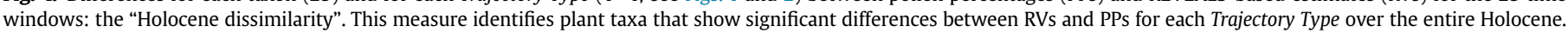

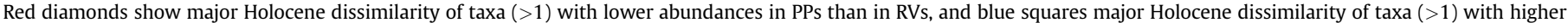

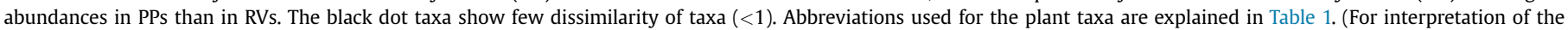
references to colour in this figure legend, the reader is referred to the web version of this article.) 

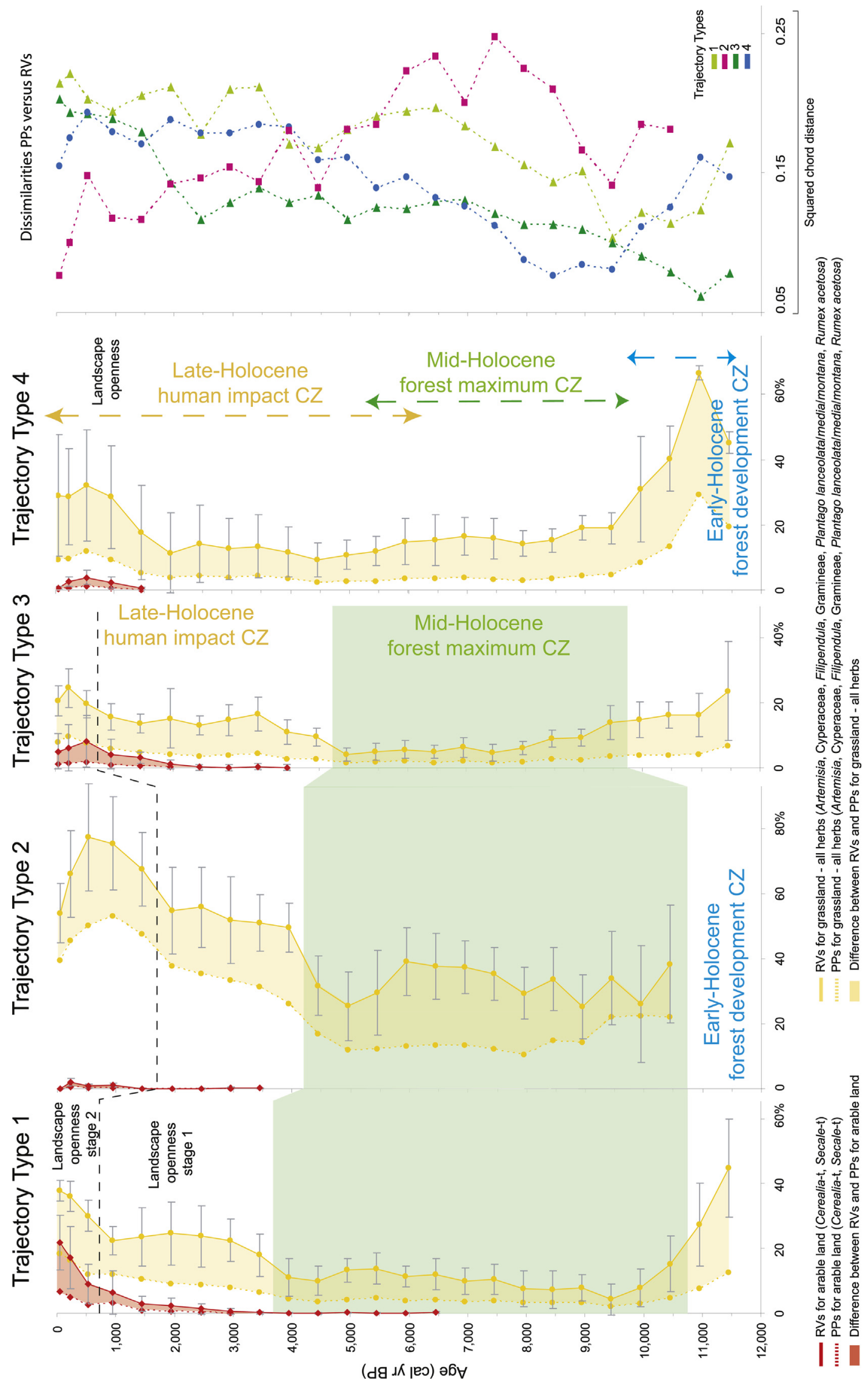
differences in taxon abundance between RVs and PPs are (Fig. 4):

- Trajectory Type 1: PPs of Pinus, Alnus, and Quercus are higher and those of Gramineae, Corylus, and Ulmus are lower than in RVs;

- Trajectory Type 2: PPs of Pinus, Betula, and Alnus are higher and those of Cyperaceae, Corylus, and Gramineae are lower than in RVs;

- Trajectory Type 3: PPs of Pinus, Alnus, and Betula are higher and those of Gramineae, Picea, and Tilia are lower than in RVs;

- Trajectory Type 4: PPs of Pinus and Betula are higher and those of Picea, Gramineae, and Cyperaceae are lower than in RVs.

\subsection{Differences in regional taxa composition between PP- and RV- based results}

In most of the study area, except for Scotland and Ireland (Trajectory Type 2), the squared chord distances between PPs and RVs decrease at the beginning of the Holocene, before gradually increasing towards the present (Fig. 5). In contrast, Trajectory Type 2 shows an increase in squared chord distances until ca 7200 cal yr BP, followed by a decrease towards the present-day. One of the likely reasons for these trends is the dominance of Calluna (both PPs and RVs) in the late-Holocene and the generally low difference between PPs and RVs of Calluna, as seen in Fig. 4.

In order to assess human impact on landscapes at a regional scale, we now focus on the extent of grassland and arable areas. At the beginning of the Holocene, the PPs of grassland taxa are lower than the RVs by $26 \%, 13 \%$, and $28 \%$ in Trajectory Types 1,3 , and 4 , respectively (Fig. 5). These numbers represent the mean percentage values of the grassland PPs minus those of RVs over the "earlyHolocene forest development" CONISS Zone (CZA, see Section 4.4 and Fig. 6). For the "mid-Holocene forest maximum" CONISS Zone (CZB), both PP and RV grassland values tend to be lower but closer to each other on average than in CZA; the PPs of grassland taxa are lower than the RVs by $6.5 \%, 5 \%$, and $11 \%$ in Trajectory Types 1,3 , and 4 , respectively. For Trajectory Type 2 (that does not include the earlyHolocene), PPs are lower than RVs by $23 \%$ during the period $8700-$ 5700 cal yr BP. In Trajectory Type 1, the first indication of arable land occurs at 6700 cal yr BP for both RVs and PPs; however, uncertainties are high for the RVs. Over the last 5000 years, the RVs exhibit two stages of increased deforestation while PPs show only one (Fig. 5). The first stage (3700-700 cal yr BP in Trajectory Type 1, 4200-1700 cal yr BP in Trajectory Type 2, and 4700-700 cal yr BP in Trajectory Type 3 ) is only recorded for RVs and corresponds to a clear increase in grassland, and the occurrence of arable land (with high uncertainties). On average, PPs of the grassland taxa are much lower than RVs by $13.5 \%, 20 \%$, and $10 \%$ in Trajectory Types 1,2 , and 3 , respectively (Fig. 5). The second stage (700-0 cal yr BP in Trajectory Types 1 and 3, and 1700-0 BP in Trajectory Type 2) is recorded for both PPs and RVs and corresponds to a second distinct increase in grassland taxa and a rise in arable-land indicators (with lower uncertainties than the first stage). On average, PPs of the grassland taxa are lower than RVs by $19 \%, 21 \%, 13.5 \%$, and $19.5 \%$ in Trajectory Types $1,2,3$, and 4, respectively. PPs of the arable-land taxa are also lower than the RVs, but the uncertainties for the RVs are still high, making the differences difficult to assess exactly.
4.4. Differences in timing of Holocene regional taxa compositional change between PP- and RV-based results

Not only the relative importance (highest value of total sum-ofsquares), but also the timing of transitions can differ between the RV- and PP-based clusterings or zonations. For simplicity, CONISSzones and CONISS-subzones (CZ) were defined using different values of the CONISS sum-of-squares depending on Trajectory Type and result type (RVs or PPs) as follows (Fig. 6):

- CZA: early-Holocene forest development

- CZB: mid-Holocene forest maximum

- $\mathrm{CZB}_{1}$ : forest expansion

$-\mathrm{CZB}_{2}$ : forest optimum

- CZC: late-Holocene human impact

$-\mathrm{CZC}_{1}$ : spruce forest stage

For most Trajectory Types, the largest CONISS groups (highest total sum-of-squares) separate zones CZA and CZB (grouped together) from zone $\mathrm{CZC}$ when RVs are used, while they separate CZA from CZB and CZC (grouped together) when PPs are used.

\subsubsection{Trajectory Type 1}

The end of CZA occurs earlier for RVs $(10,700 \mathrm{cal}$ yr BP) than for PPs $(10,200$ cal yr BP) (Fig. 6). CZB 1 is longer for RVs $(10,700-$ 7700 cal yr BP) than for PPs (10,200-7700 cal yr BP). The difference in age is mainly due to the higher values of Pinus in PPs than RVs and the lower abundances of Corylus and Ulmus in PPs than RVs (Fig. 7). The time length of $\mathrm{CZB}_{2}$ is similar for PPs and RVs (77003700 cal yr BP); the PP-based clustering is less significant than the RV-based one because of the strong influence of Pinus PPs on the analysis (Fig. 7). The beginning of CZC is at $3700 \mathrm{cal} \mathrm{yr} \mathrm{BP} \mathrm{for} \mathrm{both}$ RVs and PPs (Fig. 6).

\subsubsection{Trajectory Type 2}

CZB starts at 10,700 cal $\mathrm{yr}$ BP. The beginning of $\mathrm{CZB}_{2}$ is at 8700 cal yr BP for both RVs and PPs (Fig. 6); the duration of this subzone is shorter for RVs (8700-4200 cal yr BP) than for PPs (8700-3700 cal yr BP). The difference in age of the end of $\mathrm{CZB}_{2}$ is mainly influenced by differences between the PPs and RVs and the estimated abundances of Calluna and Gramineae, and also partly of Pinus and Alnus (Fig. 4).

\subsubsection{Trajectory Type 3}

CZA ends at 9700 cal yr BP for both RVs and PPs (Fig. 6). PPs and RVs show a similar timing for $\mathrm{CZB}_{1}(9700-7700$ cal yr BP). The duration of $\mathrm{CZB}_{1}$ is shorter for RVs $(7700-4700$ cal yr BP) than for PPs (7700-3700 cal yr BP). CZC starts earlier for RVs (4700 cal yr BP) than for PPs (3700 cal yr BP). Picea is the main taxon influencing this age difference (note the strong influence of Picea in the time window 1700-1200 cal yr BP for Trajectory Type 3 in Fig. 7).

\subsubsection{Trajectory Type 4}

CZA ends at 9700 cal yr BP for both RVs and PPs (Fig. 6). The duration of $\mathrm{CZB}_{1}$ is greater for RVs (9700-7700 cal yr BP) than for PPs (9700-8200 cal yr BP). CZB 2 is also longer for RVs (77005200 cal yr BP) than for PPs (8200-6200 cal yr BP). Pinus and Betula are the two major taxa that characterise $\mathrm{CZB}_{2}$ for both PPs and RVs

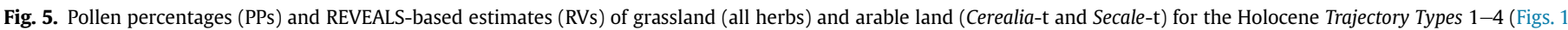

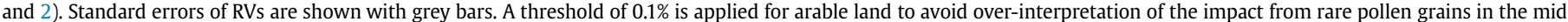

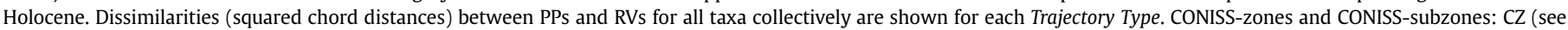
Fig. 6). 


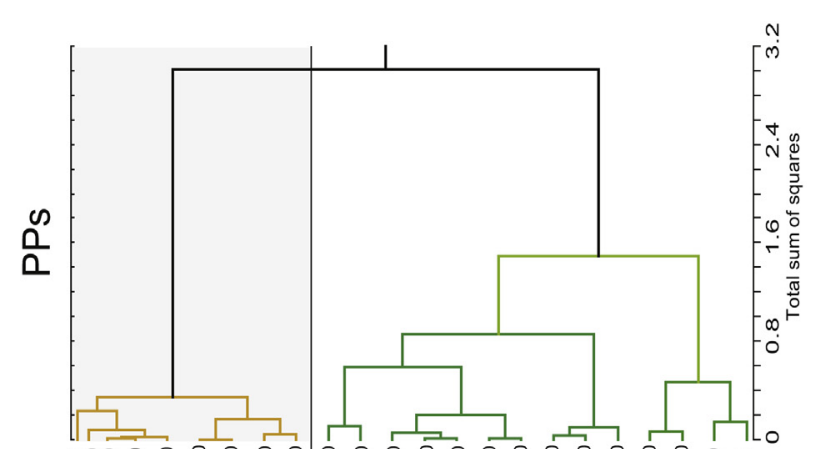

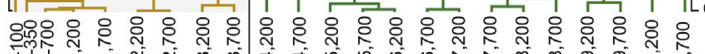

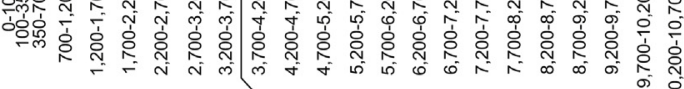
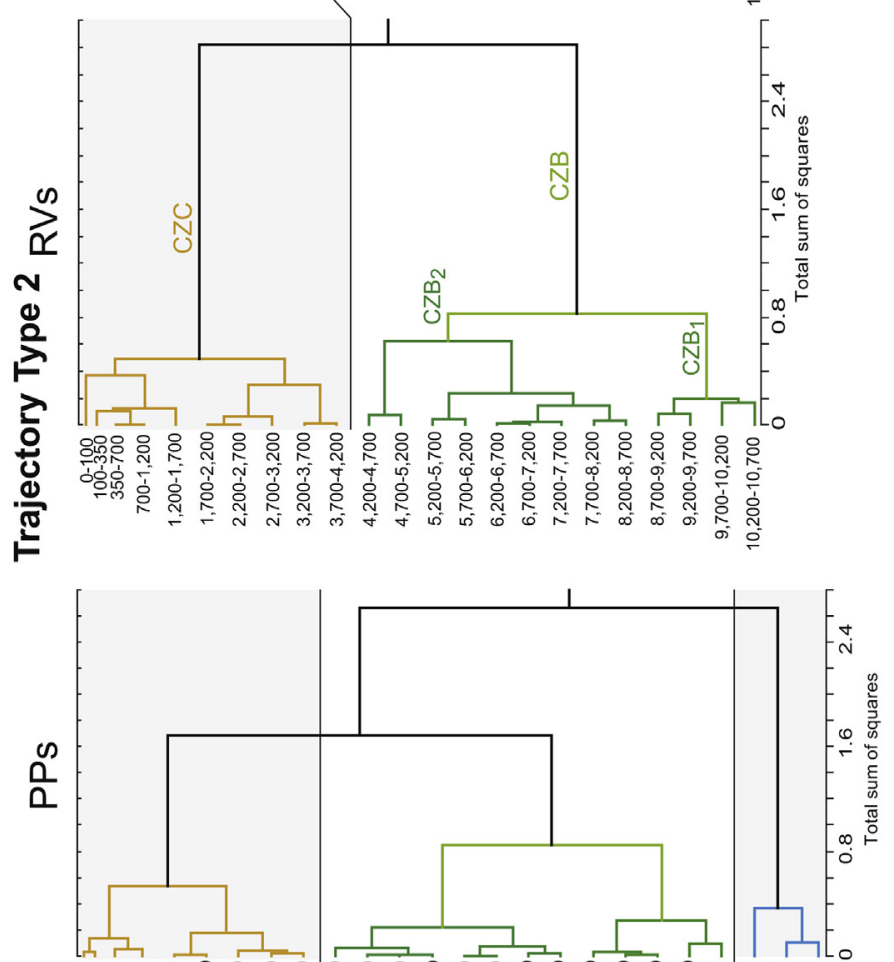

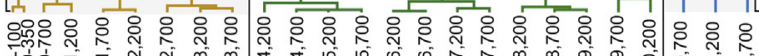

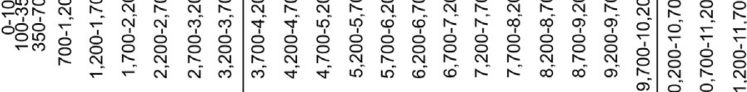

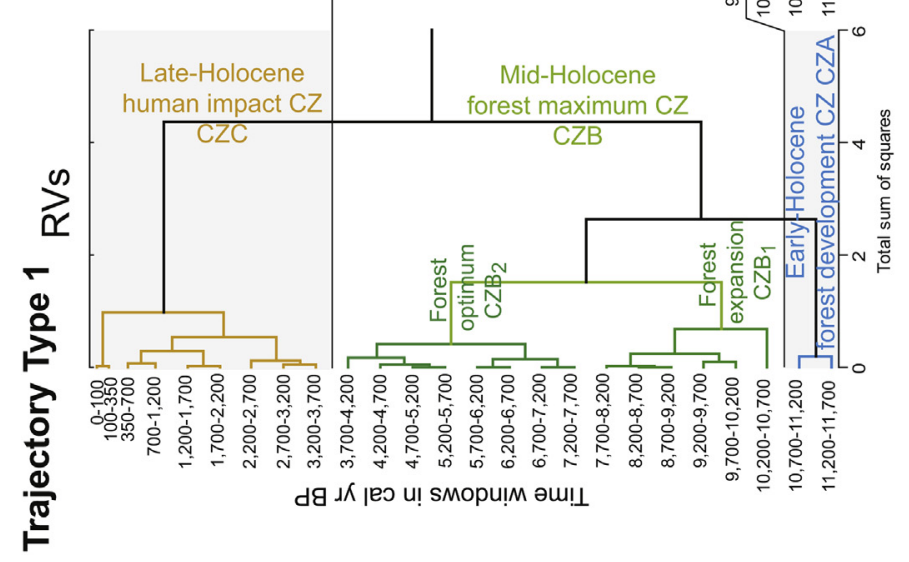

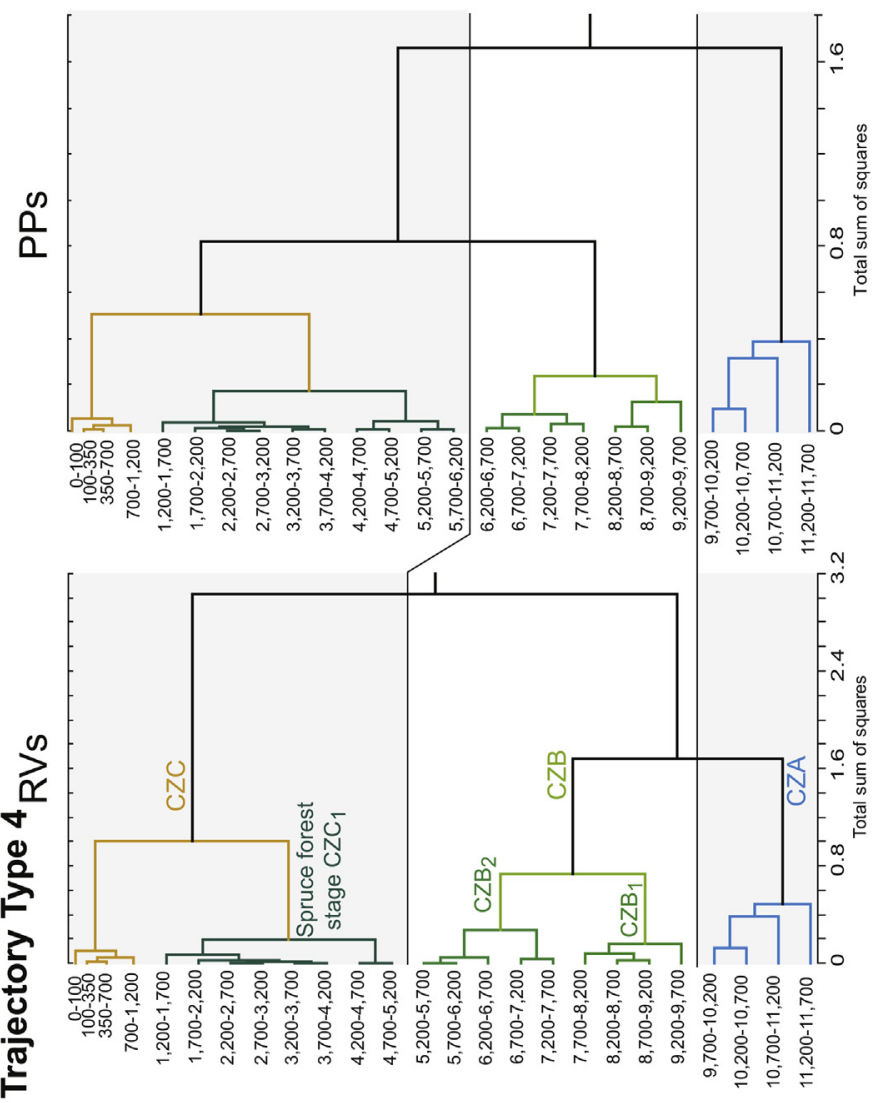

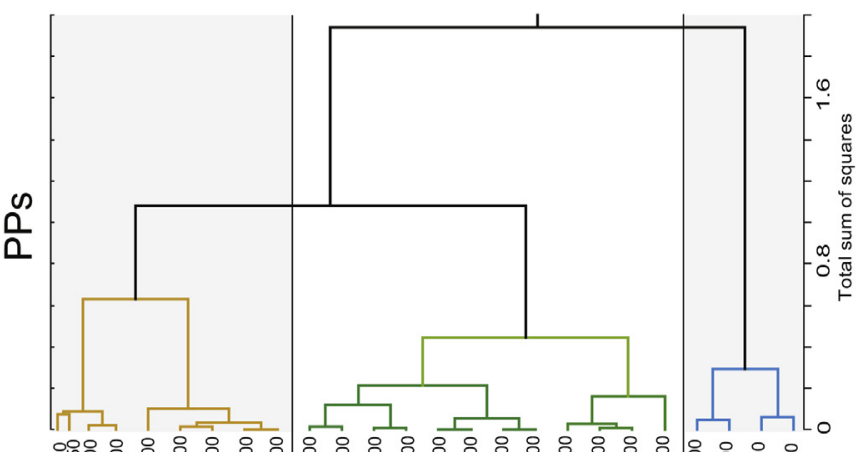

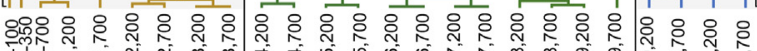

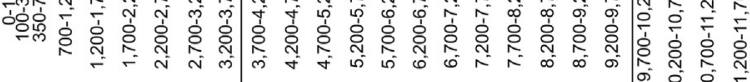

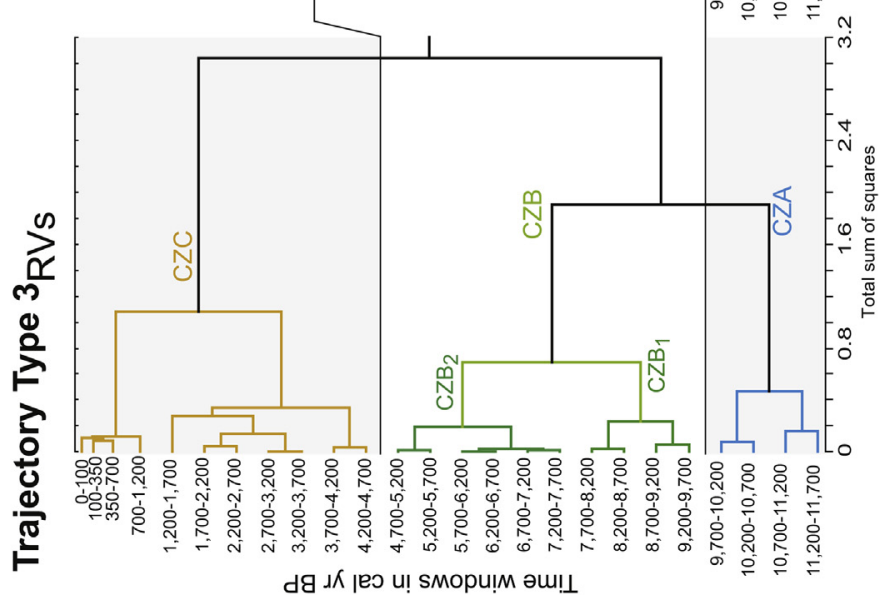

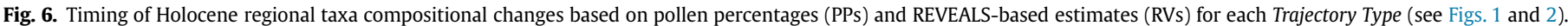

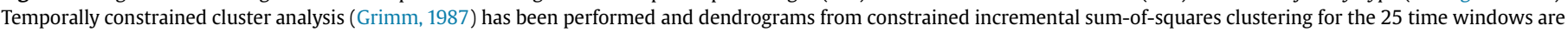

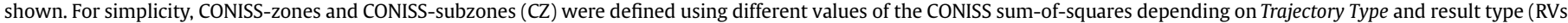
or PPs) (see main text for further explanation). 

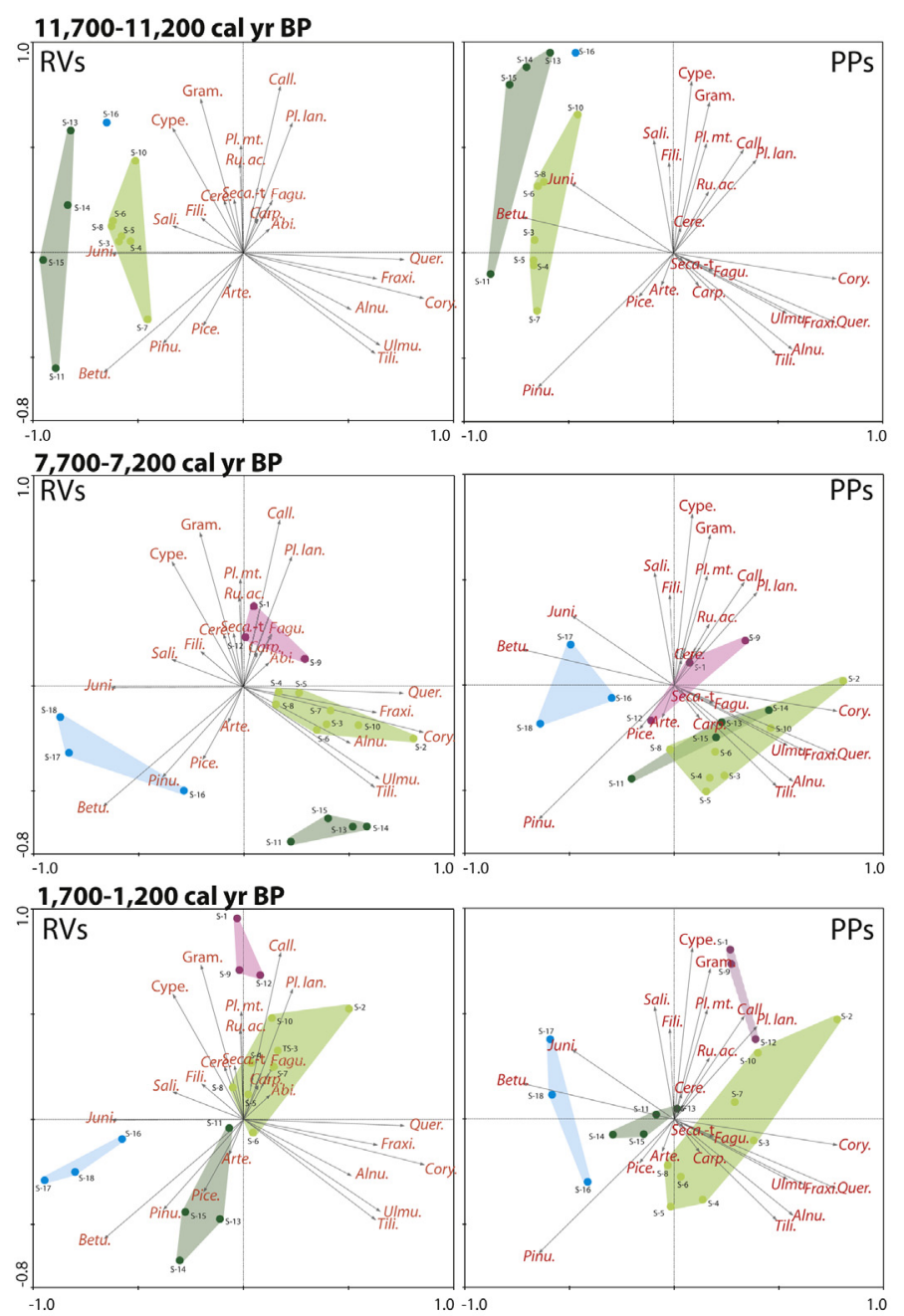

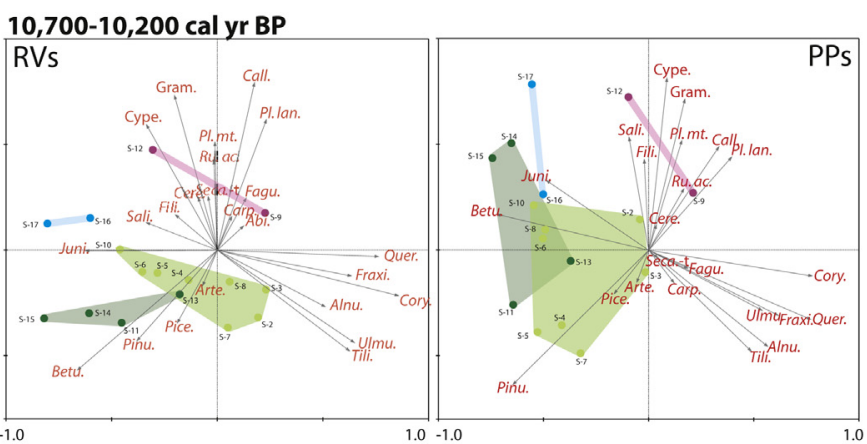

$5,700-5,200$ cal yr BP

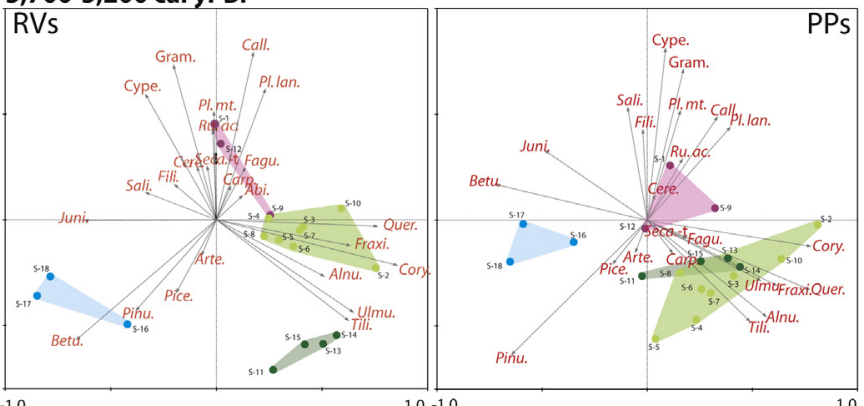

100-0 cal yr BP

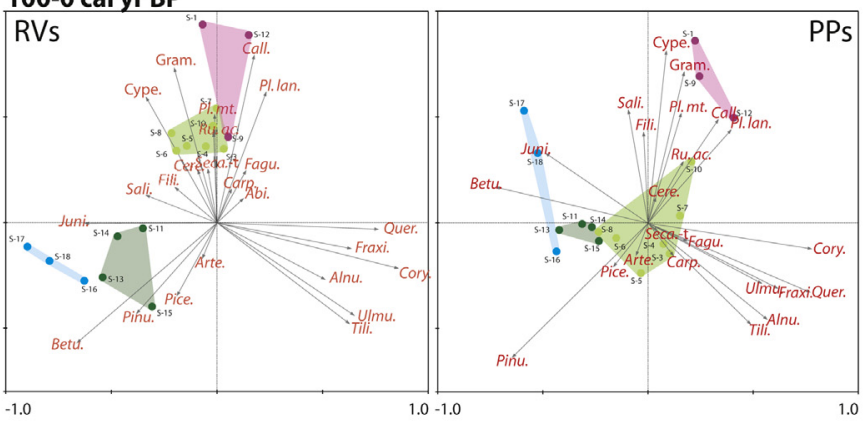

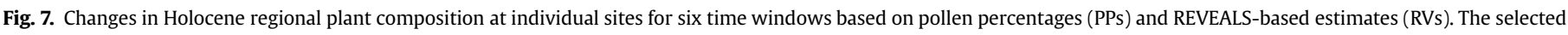

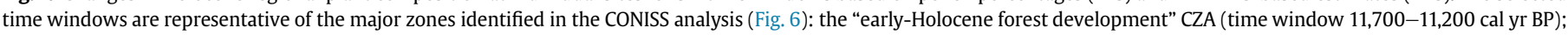

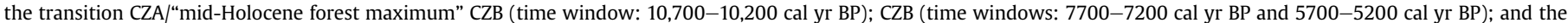

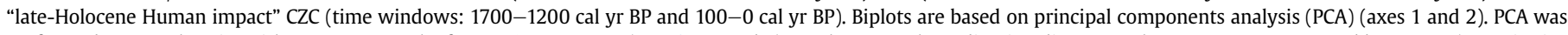

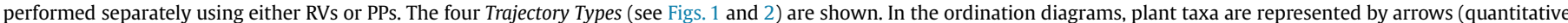

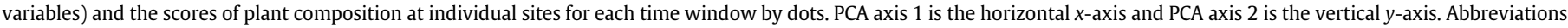
used for the plant taxa are explained in Table 1. S: sites.

(Fig. 7). CZC includes an "expansion in Picea" subzone ( $\left.\mathrm{CZC}_{1}\right)$ prior to an increase in landscape openness. The duration of $\mathrm{CZC}_{1}$ is shorter for RVs (5200-1200 cal yr BP) than for PPs (6200-1200 cal yr BP).

\subsection{Differences in regional taxa rate of change, turnover, and} evenness between PP- and RV-based results

\subsubsection{Differences in rate of change}

Overall, the rates of change throughout the Holocene are lower for PPs than for RVs (Fig. 8). At the beginning of the Holocene, the rates of change are higher for RVs than for PPs. The boundary CZA/ CZB corresponds to a decrease in the rates of change that are more pronounced for RVs than for PPs. The rates of change are lower during CZB for both RVs and PPs. In contrast, the boundary CZB/CZC (from 5200 cal yr BP) is characterised by a clear rise in the rates of change of RVs over most of the study area, while PPs do not exhibit any marked changes. Over the last 3700 years, the rates of change for RVs first fluctuate and then increase in two steps, ca 22001200 cal yr BP and ca 1200-0 cal yr BP. There is a slight increase in the rates of change for PPs at 1700 cal yr BP before a significant rise over the last 700 years.

\subsubsection{Differences in turnover}

For the Holocene as a whole, there is a gradual decrease in turnover (Fig. 8). This is higher for RVs than for PPs at the beginning of the Holocene, in particular for Trajectory Type 1. It decreases gradually during CZB and more abruptly at the boundary CZB/CZC both in terms of RVs and PPs. Turnover decreases again between 3700 and $500 \mathrm{cal}$ yr BP and increases over the last 500 years for both RVs and PPs.

\subsubsection{Differences between $R V$ and PP evenness (i.e. equitability of dominant taxa)}

At the beginning of the Holocene, RV and PP evenness is similar between Trajectory Types 1, 3, and 4; however, Trajectory Type 2 shows greater evenness than the other Trajectory Types (Fig. 8). Between 9200 and 6700 cal yr BP, both RV and PP evenness gradually increase over the study area except for PP evenness in 


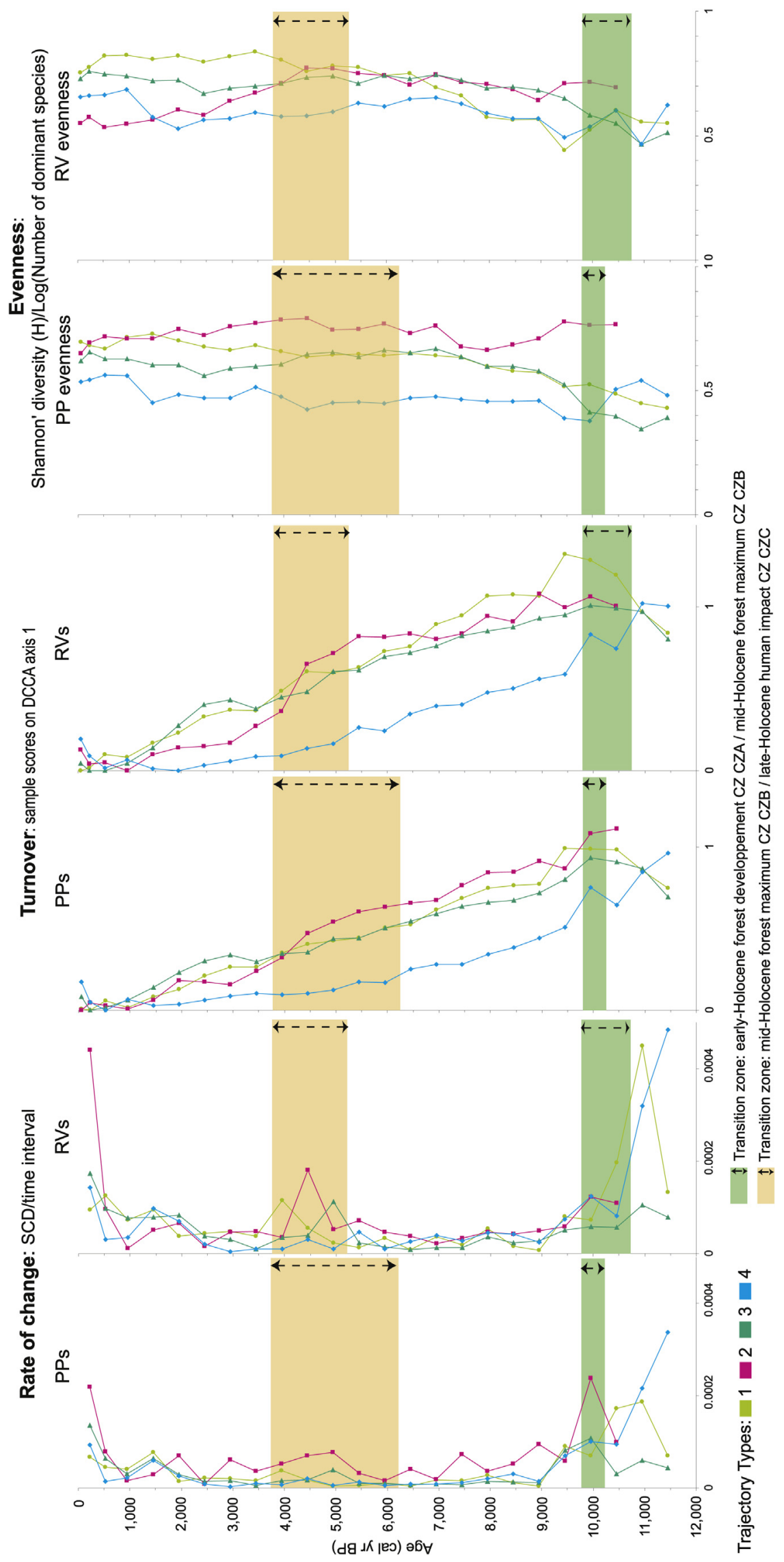

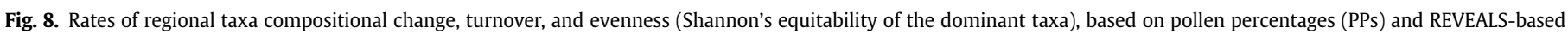
estimates (RVs). The bands through the diagrams represent the transition zones of the CONISS major zones (see Fig. 6), CZA/CZB and CZB/CZC. 
Trajectory Types 2 and 4 . The values of RV evenness become increasingly similar between all Trajectory Types during CZB, while PP evenness differs between Trajectory Types 2 and 4 and 1 and 3. At 6700 cal yr BP, RV and PP evenness does not increase further, except for Trajectory Type 1. From the CZB/CZC boundary, RV evenness becomes markedly different between Trajectory Types 1, 2, and 3 up to the present; PP evenness of Trajectory Types 2 was already different. RV evenness highly differs between Trajectory Types 1 and 2 over the last 2700 years; PP evenness is similar between these Trajectory Types and for this period.

\section{Discussion}

Because the REVEALS model corrects for biases in pollen percentages due, in particular, to intraspecific differences in pollen productivity and dispersal (Sugita et al., 2010), the RVs are thus potentially more informative than PPs for the reconstruction and evaluation of past vegetation change. Accordingly, the analyses of RVs and PPs presented in this paper provide new insights into the long-term history of vegetation and the timing and magnitude of past land-cover change in different sub-regions of northern Europe. We discuss here how REVEALS-based vegetation reconstruction improves our understanding of the major changes in Holocene regional vegetation composition compared to PPs. We focus in particular on human impact on regional vegetation dynamics, taxa abundance and composition, and on sub-continental patterns of reconstructed regional vegetation diversity within and between different modern biomes in northern Europe.

\subsection{Beginning of the Holocene: forests were more open at the regional spatial scale than previously assumed}

At the beginning of the Holocene, most of the study area was covered by open forest with grasses, shrubs, and early-successional trees such as Betula and Pinus. The ameliorating climate following increased summer insolation (Imbrie et al., 1992) was probably one of the major causes of this development. The earliest Holocene is generally considered to have been a time of low human impact on the northern European landscapes (Behre, 1988).

Rapid changes in regional taxa composition, high turnover, and gradual increases in RV evenness typify this period (Fig. 9), and these are related to the expansion of the existing tree cover and the arrival of new arboreal taxa from their glacial refugia. The RVs of grassland are generally higher than the PPs, which implies that landscapes were more open than was thought earlier on the basis of PPs. These results support the idea that pollen records, when expressed as PPs, do not provide a realistic picture of forest cover or forest openness in northern Europe at the beginning of the Holocene as assumed and discussed by a number of authors (e.g. Vera, 2000; Svenning, 2002; Mitchell, 2005) and already demonstrated by some empirical palaeoecological studies based on LRAs reconstructions (Sugita et al., 2008; Cui et al., 2013) or coleopteran data (Whitehouse and Smith, 2004; Olsson and Lemdahl, 2009, 2010).

\subsection{First anthropogenic impact on regional land-cover change and diversity in the mid-Holocene}

During the mid-Holocene, the northward spread of Corylus, Ulmus, Tilia, Quercus, and Alnus characterised most of the study region. Temperate forests replaced the Betula- and Pinus-dominated forests that prevailed in many areas in the early-Holocene (e.g. Birks, 1986). At the same time, the cover of Pinus, Betula, and Juniperus increased in Trajectory Type 4. The development of broadleaved deciduous forests in northern Europe and Pinus-Betula-
Juniperus forests further north corresponds to the relatively warm stage of the Holocene. This period is also distinguished by the first significant deforestation by Neolithic people that transformed wooded areas into fields, pastures, meadows, and heathlands.

The high RVs of Ulmus and Corylus at 10,700 cal yr BP in Trajectory Type 1 indicate a woodland expansion that is earlier than suggested by the PPs (ca 10,200 cal yr BP) and earlier than the general increase of Corylus-PPs in central Europe recorded at ca 10,550-10,400 cal yr BP (e.g. Bos, 2001; Giesecke et al., 2011). This expansion coincides with a high and rapid regional taxa compositional turnover during the early-Holocene (Fig. 9). Similar trends in vegetation change based on PPs were also found in northernmost Europe and eastern North America (e.g. Jacobson et al., 1987; Grimm and Jacobson, 1992; Birks and Birks, 2008).

Between 10,200 and 6700 cal yr BP, the abundance of tree taxa gradually increased over most of the study area, resulting in a progressively enhanced regional RV evenness (Fig. 9). In contrast, RV turnover decreases, as is also seen in the trends based on PPs found over both northernmost Europe and eastern North America (Grimm and Jacobson, 1992; Birks and Birks, 2008). However, a regional increase in grassland cover between 7700 and 4700 cal yr BP in Trajectory Type 1 and between 7700 and 5700 cal yr BP in Trajectory Type 2 was followed by a decline, and then a final rise in the late-Holocene. Natural processes such as bog development, fire, drought (or other climatic characteristics), and pathogen outbreaks may have influenced the regional patterns (e.g. Brown, 1997; Fyfe et al., 2013), while grazing animals may have maintained open areas (Vera, 2000). To decipher which of these various factors have been most decisive depending on the time period is not the subject of this paper. Rather, we focus on humaninduced factors. The regional increase in grassland in Trajectory Type 1 may be related to the first forest clearance due to the onset of farming, as it is contemporary with the start of the "Linearbandkeramik" culture at $7600-7500$ cal yr BP in central Europe (Kalis et al., 2003; Shennan, 2009). The current archaeological understanding of "Linearbandkeramik" agriculture suggests the occurrence of permanent plots and garden cultivation at that time (van Andel and Runnels, 1995; Bogaard, 2002, 2005). However, it should be emphasised that these REVEALS-based estimates describe vegetation openness at the regional spatial scale and, therefore, fine-scale human-induced forest openness will not be visible even if deforestation is locally large in area.

From 6700 to 5700 cal yr BP, general trends in RV evenness do not increase further (Fig. 9) except for Trajectory Type 1 . The rise in RV evenness up to $6700 \mathrm{cal}$ yr BP coincides with the gradual increase in forest cover, and the regular RV evenness afterwards coincides with the forest maximum. The maximum extent of the wooded area may have corresponded to the warmest period of the Holocene in northern Europe, prior to the cooling trend which followed declining summer insolation (Imbrie et al., 1992). According to proxy-climate records and climate-model output, the climatic transition occurred between ca 8000 and 5500 cal yr BP in northern Europe (e.g. Matthews et al., 2000; Korhola et al., 2002; Seppä et al., 2002; Larocque and Hall, 2004; Nesje et al., 2005; Velle et al., 2005; Renssen et al., 2009) and between ca 8500 and 5000 cal yr BP in central Europe and the Alps (e.g. Haas et al., 1998; Nicolussi and Patzelt, 2000; Hormes et al., 2001; Heiri et al., 2003; Renssen et al., 2009). Changes in RV evenness may highlight the end of the warmest period in the Holocene for northern Europe.

In Trajectory Type 1, the first recurrences of regional indications of arable land (essentially recorded by Cerealia-pollen type) from ca 6700 cal yr BP (Fig. 9; these regional recurrences of arable-land indicators are mostly influenced by sites 6 and 7) might relate to the onset of human impact on plant composition and RV evenness. Land-cover reconstructions in northern Germany and Denmark 

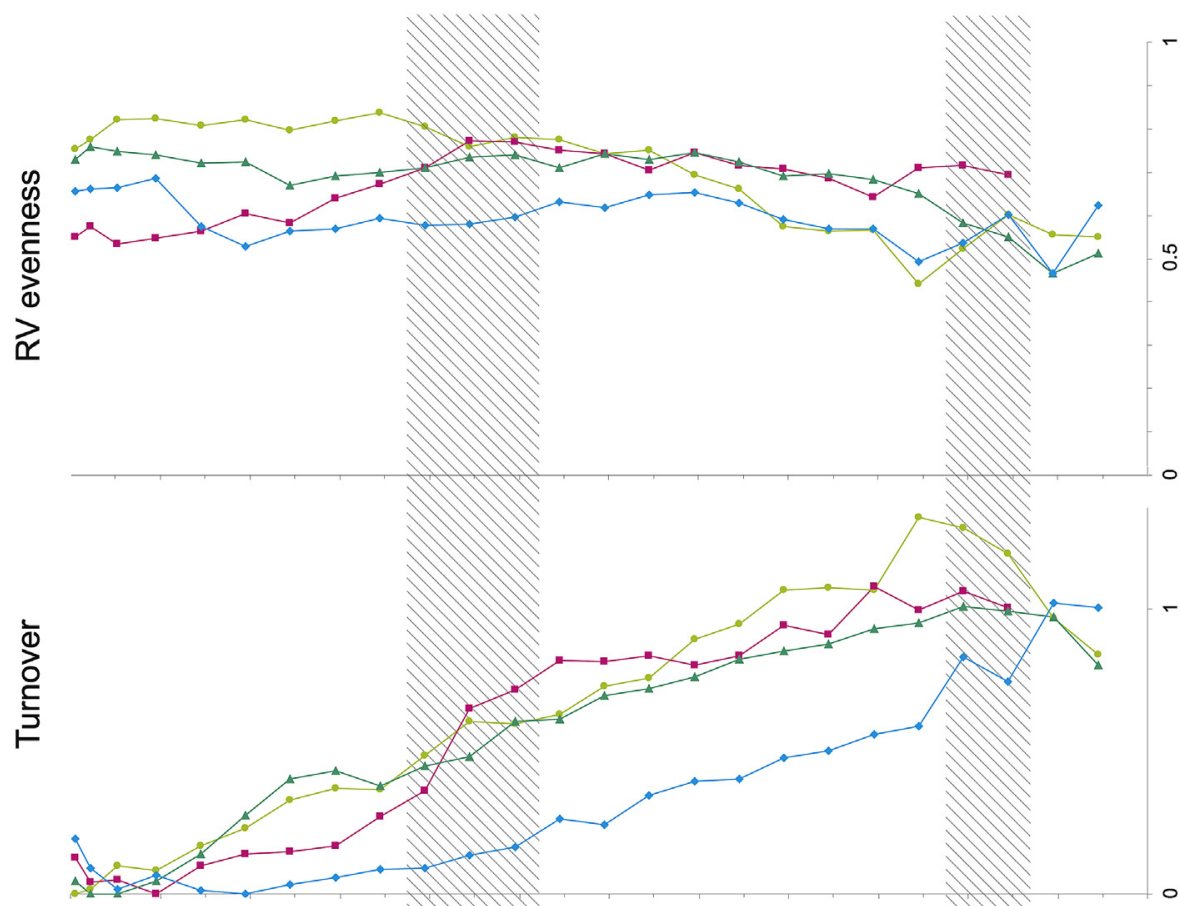

N
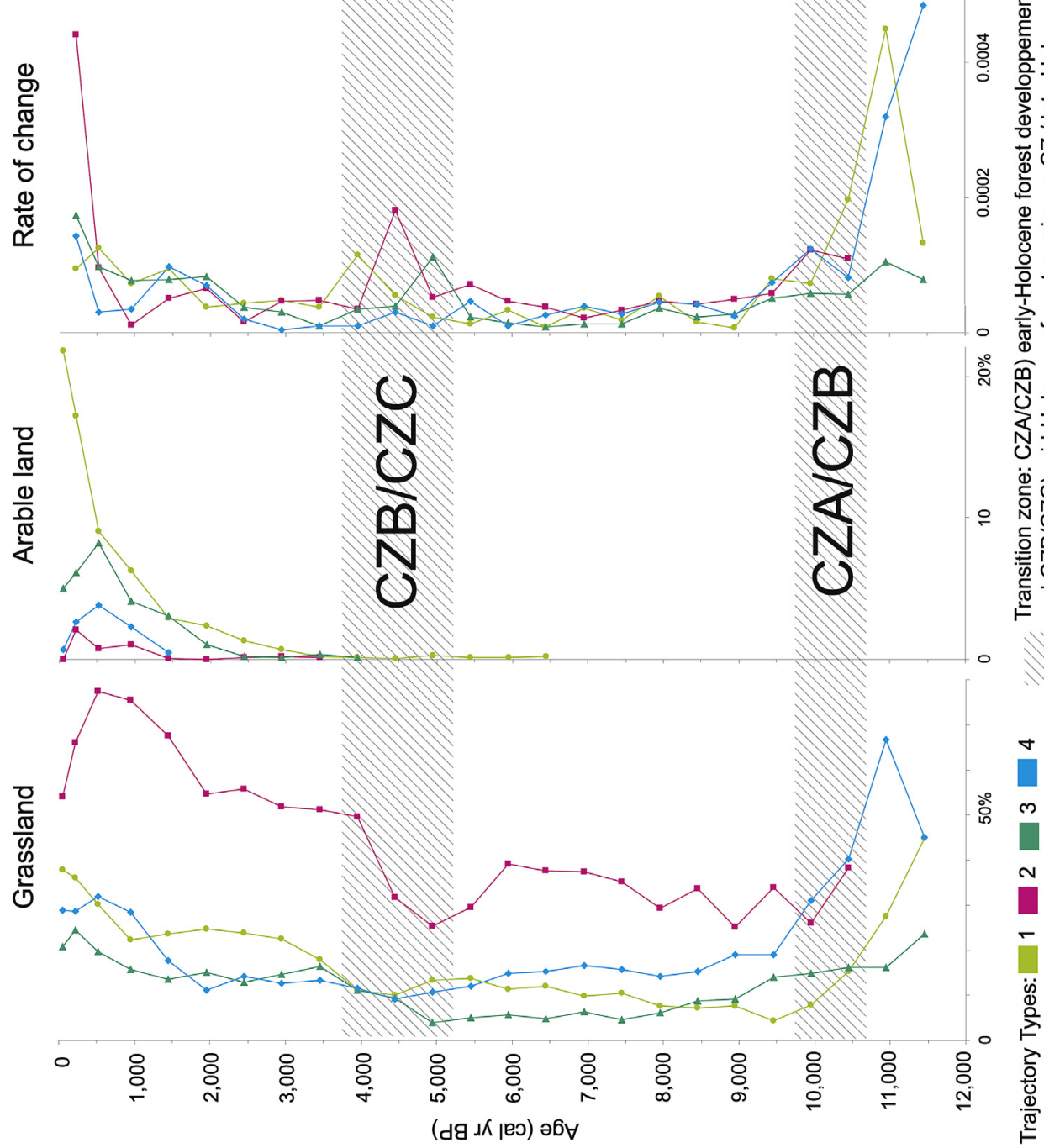

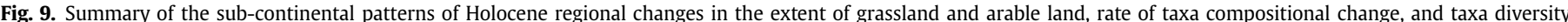

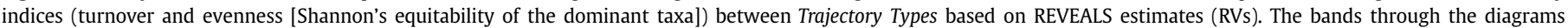
represent the transition zones of the CONISS major zones (see Fig. 6), CZA/CZB and CZB/CZC. 
based on sites that are not included in our target sites (Nielsen et al., 2012) also show increases in deforested land since 6700 cal yr BP in the southern parts of the study region and since $5000 \mathrm{cal}$ yr BP in the northern parts. In the British Isles, land-cover reconstruction and pollen-based pseudo-biomisation (Fyfe et al., 2010, 2013; Woodbridge et al., in press) show that land-cover changes were influenced by Neolithic populations from $\sim 6000$ cal yr BP. Expansion of the open landscape due to human activities also took place in southern Sweden from ca 6000 cal yr BP (Berglund et al., 2008). Thus, Neolithic land-use appears to have influenced land cover through deforestation in the regions represented in Trajectory Type 1 over the last ca 6700 cal yr BP. Note that we speak here at large regional scale and there is no doubt that the age of these first land-use impacts on land cover differs locally. However, the regional climate was still the main driver of the major changes in vegetation.

\subsection{Intensification of human impact on regional land-cover and its diversity from ca 5200 cal yr BP}

A strong increase in the regional cover of both grassland and arable land (Fig. 9) marks the transition between the midHolocene forest maximum and the late-Holocene human impact CZs B and C (5200-3700 cal yr BP). The intensification of forest transformation to arable fields and pasture lands, and the acquisition of wood for building and fuel, occurred in response to the increasing needs of human populations. The anthropogenic nature of this shift in northernmost Europe (Trajectory Type 4) is not clear here, as it was probably masked by the large expansion of Picea recorded in southern Finland (site 16). Except for northernmost Europe, deforestation increased at 5200 cal yr BP over most of the study area. The timing of this extensive forest reduction agrees with archaeological and palaeoecological data. Neolithic farming was largely established in Europe by ca 6000-5500 cal yr BP (Shennan, 2009; Lemmen and Wirtz, in press) and the first significant influences on the Neolithic landscape are detected in pollen records from around 5500-5000 cal yr BP (Behre, 1988; Haas et al., 2003). Grassland and arable areas are largely under-represented by PPs compared to RVs; thus the RVs suggest more extensive forest openness and/or removal than was previously thought on the basis of PPs only. Before 5200 cal yr BP, Neolithic forest clearance may have occurred to create permanent fields over small areas (Bogaard, 2002, 2005; Karlis et al., 2003) along with pasture for domestic animals such as goats, sheep, and cattle in northern Europe. From 5200 cal yr BP, the population increased and the spread of sedentism contributed to the increase of deforestation in the Late Neolithic and Early Bronze Age, depending on geographical location. Thus, the transition between the mid-Holocene forest maximum CZB and the late-Holocene human impact CZC marks the beginning of more extensive deforestation that dramatically affected the rate of taxa compositional change, turnover, and RV evenness.

Over the last $\sim 2000$ years, arable-land cover strongly increased in the entire study area, related to renewed acceleration in rates of change and the lowest turnover in the Holocene (Fig. 9). These changes were likely caused by regional agricultural intensification and population growth. Over the last $\sim 200$ years, the nature of human influence changes; cultivated land was abandoned, and woodland was planted in northern Europe, causing a dramatic change in regional taxa composition and turnover. The decline of landscape diversity during recent centuries owing to modern agriculture and forestry (large cultivated fields and the planting of mono-specific forests), with important losses of habitat and species diversity (e.g. Berglund et al., 1991, 2008; Fredh et al., 2012, 2013) is not related to a distinct fall in RV evenness, although there is a slight decrease over the last 350 years.

\section{Conclusions}

This study provides valuable insights into past regional vegetation history of northern Europe as follows:

- The REVEALS estimates (RVs) rather than pollen percentages (PPs) are found to characterise differing regional vegetation taxa compositions better over time and space.

- Changes of regional vegetation evenness (Shannon's equitability), turnover, and rate of change, over time and space, are more distinct when REVEALS-based estimates of vegetation composition are used instead of pollen percentages.

- The timing and magnitude of changes in past regional plant composition are also different between REVEALS estimates and pollen percentages.

- The REVEALS-based estimates suggest that regional landscape openness in the early-Holocene, the influence of Neolithic deforestation on regional plant composition in the midHolocene, and regional anthropogenic deforestation during the late-Holocene were greater than previously interpreted from pollen percentages.

The analyses and assessment presented in this paper strongly suggest that REVEALS-based quantitative reconstructions of regional vegetation change are very useful to use along with the pollen records expressed as pollen percentages and accumulation rates in the study of past regional plant composition and diversity. Such reconstructions and their careful analysis provide new perspectives on the extent of human disturbance of the Holocene regional vegetation and its consequences in terms of regional plant cover, composition, turnover, and evenness, all critical issues in the assessment of human impact on terrestrial vegetation and the study of long-term biodiversity and land cover-climate interactions.

\section{Acknowledgements}

This work is a part of the LANDCLIM (LAND cover - CLIMate interactions in NW Europe during the Holocene) project and research network coordinated by M.-J. Gaillard and sponsored by the Swedish (VR) and Nordic (NordForsk) Research Councils 20092011. LANDCLIM is also a contribution to the Strategic Research Area MERGE (ModElling the Regional and Global Earth system; http://www.cec.lu.se/research/merge) coordinated by M. Rummukainen (Lund University, Sweden) and sponsored by the Swedish Research Council (VR) 2010-2014, and to the IGBP-PAGES-Focus 4 programme 2009-2014 (http://www.pages-igbp.org/science/foci/ focus-4). We thank all members of the LANDCLIM network who contributed pollen data and for useful discussions and advices, as well as J.S. Carrión and the anonymous reviewers for valuable comments and suggestions. Other funding sources include the Faculty of Health and Life Sciences of Linnaeus University (L. Marquer, M.-J. Gaillard, A.-K. Trondman, S. Sugita), the French CNRS (F. Mazier) and the King Carl XVI Gustaf's Foundation for Environmental Sciences in Sweden (S. Sugita.). H.J.B. Birks acknowledges the assistance of C.R. Jenks. This is a contribution from the Bjerknes Centre for Climate Research (H.J.B. Birks and A.E. Bjune).

\section{Appendix A. Supplementary data}

Supplementary data related to this article can be found at http:// dx.doi.org/10.1016/j.quascirev.2014.02.013. 


\section{References}

Abraham, V., Kozakova, R., 2012. Relative pollen productivity estimates in the modern agricultural landscape of Central Bohemia (Czech Republic). Rev. Palaeobot. Palynol. 179, 1-12.

van Andel, T.H., Runnels, C.N., 1995. The earliest farmers in Europe. Antiquity 69, $481-500$.

Behre, K.E., 1988. The role of man in European vegetation history. In: Huntley, B., Webb, T. (Eds.), Vegetation History. The Netherland, Dordrecht, pp. 633-672.

Berglund, B.E., 1991. The cultural landscape during 6000 years in southern Sweden: the Ystad project. Ecol. Bull. 41, 495.

Berglund, B.E., Gaillard, M.J., Björkman, L., Persson, T., 2008. Long-term changes in floristic diversity in southern Sweden: palynological richness, vegetation dynamics and land-use. Veg. Hist. Archaeobot. 17, 573-584.

Birks, H.J.B., 1986. Late-Quaternary biotic changes in terrestrial and limnic environments, with particular reference to north-west Europe. In: Berglund, B.E. (Ed.), Handbook of Holocene Palaeoecology and Palaeohydrology. J. Wiley \& Sons, pp. 3-65.

Birks, H.J.B., 2007. Estimating the amount of compositional change in lateQuaternary pollen-stratigraphical data. Veg. Hist. Archaeobot. 16, 197-202.

Birks, H.J.B., Birks, H.H., 2008. Biological responses to rapid climate change at the Younger Dryas-Holocene transition at Kråkenes, western Norway. Holocene 18, $19-30$.

Birks, H.J.B., Line, J.M., 1992. The use of rarefaction analysis for estimating palynological richness from Quaternary pollen-analytical data. Holocene 2, 1-10.

Birks, H.J.B., Line, J.M., Persson, T., 1988. Quantitative estimation of human impact on cultural landscape development. In: Birks, H.H., Birks, H.J.B., Kaland, P.E., Moe, D. (Eds.), The Cultural Landscape. Past, Present and Future. Cambridge University Press, Cambridge, pp. 229-240.

Blaauw, M., 2010. Methods and code for 'classical' age-modelling of radiocarbon sequences. Quat. Geochronol. 5, 512-518.

Bogaard, A., 2002. Questioning the relevance of shifting cultivation to Neolithic farming in the loess belt for Europe: evidence from the Hambach forest experiment. Veg. Hist. Archaeobot. 11, 155-168.

Bogaard, A., 2005. 'Garden agriculture' and the nature of early farming in Europe and the near east. World Archaeol. 37, 177-196.

Bos, J.A.A., 2001. Lateglacial and Early Holocene vegetation history of the northern Wetterau and the Amöneburger Basin (Hessen), central-west Germany. Rev, Palaeobot. Palynol. 115, 177-204.

ter Braak, C.J.F., Prentice, I.C., 1988. A theory of gradient analysis. Adv. Ecol. Res. 18, $271-317$.

ter Braak, C.J.F., Šmilauer, P., 2002. CANOCO Reference Manual and CanoDraw for Windows User Guide: Software for Canonical Community Ordination (Version 4,5). Microcomputer Power, Ithaca.

Broström, A., Gaillard, M.J., Ihse, M., Odgaard, V.B., 1998. Pollen-landscape relationships in modern analogues of ancient cultural landscapes in southern Sweden - a first step towards quantification of vegetation openness in the past. Veg. Hist. Archaeobot. 7, 189-201.

Broström, A., Sugita, S., Gaillard, M.J., 2004. Pollen productivity estimates for the reconstruction of past vegetation cover in the cultural landscape of southern Sweden. Holocene 14, 368-381.

Broström, A., Nielsen, A., Gaillard, M.J., Hjelle, K., Mazier, F., Binney, H., Bunting, J., Fyfe, R., Meltsov, V., Poska, A., Räsänen, S., Soepboer, W., von Stedingk, H., Suutari, H., Sugita, S., 2008. Pollen productivity estimates of key European plant taxa for quantitative reconstruction of past vegetation: a review. Veg. Hist. Archaeobot. 17, 461-478.

Brown, T., 1997. Clearances and clearings: deforestation in Mesolithic/Neolithic Britain. Oxf. J. Archaeol. 16, 133-146.

Bunting, M.J., Middleton, D., 2005. Modelling pollen dispersal and deposition using HUMPOL software, including simulating windroses and irregular lakes. Rev. Palaeobot. Palynol. 134, 185-196.

Bunting, M.J., Armitage, R., Binney, H.A., Waller, M., 2005. Estimates of "relative pollen productivity" and "relevant source area of pollen" for major tree taxa in two Norfolk (UK) woodlands. Holocene 15, 459-465.

Cui, Q.Y., Gaillard, M.J., Lemdahl, G., Sugita, S., Greisman, A., Jacobsson, G.L., Olsson, F., 2013. The role of tree composition in Holocene fire history of the hemiboreal and southern boreal zones of southern Sweden, as revealed by the application of the Landscape Reconstruction Algorithm - implications for biodiversity and climate-change issues. Holocene 23 (12), 1747-1763.

Davis, M.B., 1963. On the theory of pollen analysis. Am. J. Sci. 261, 897-912.

Fredh, D., Broström, A., Zillen, L., Mazier, F., Rundgren, M., Lagerås, P., 2012. Floristic diversity in the transition from traditional to modern land-use in southern Sweden A.D. 1800-2008. Veg. Hist. Archaeobot. 21, 439-452.

Fredh, D., Broström, A., Rundgren, M., Lagerås, P., Mazier, F., Zillén, L., 2013. The impact of land-use change on floristic diversity at regional scale in southern Sweden 600 B.C-A.D. 2008. Biogeosciences 10, 3159-3173.

Fyfe, R.M., Beaulieu, J.L., Binney, H., Bradshaw, R.H.W., Brewer, S., Flao, A. Finsinger, W., Gaillard, M.J., Giesecke, T., Gil-Romera, G., Grimm, E.C., Huntley, B., Kunes, P., Kuhl, N., Leydet, M., Lotter, A.F., Tarasov, P.E., Tonkov, S., 2009. The European Pollen Database: past efforts and current activities. Veg. Hist. Archaeobot. 18 (5), 417-424.

Fyfe, R.M., Roberts, N., Woodbridge, J., 2010. A pollen-based pseudobiomisation approach to anthropogenic land-cover change. Holocene 20, 1165-1171.
Fyfe, R.M., Twiddle, C., Sugita, S., Gaillard, M.J., Barratt, P., Caseldine, C.J., Dodson, J., Edwards, K.J., Farrell, M., Froyd, C., Grant, M.J., Huckerby, E., Innes, J.B., Shaw, H., Waller, M., 2013. The Holocene vegetation cover of Britain and Ireland: overcoming problems of scale and discerning patterns of openness. Quat. Sci. Rev. 73, 132-148.

Gaillard, M.J., Birks, H.J.B., Ihse, M., Runborg, S., 1998. Pollen/landscape calibrations based on modern pollen assemblages from surface-sediment samples and landscape mapping - a pilot study in South Sweden. In: Gaillard, M.J. Berglund, B.E. (Eds.), Palaeoklimaforschung/Palaeoclimate Research 27, Quantification of Land Surfaces Cleared of Forests during the Holocene - Modern Pollen/Vegetation/Landscape Relationships as an Aid to the Interpretation of Fossil Pollen Data. Gustav Fischer Verlag, Stuttgart, pp. 31-52.

Gaillard, M.J., Sugita, S., Bunting, M.J., Middleton, R., Broström, A., Caseldine, C. Giesecke, T., Hellman, S.E.V., Hicks, S., Hjelle, K., Langdon, C., Nielsen, A.B. Poska, A., von Stedingk, H., Veski, S., POLLANDCAL members, 2008. The use of modelling and simulation approach in reconstructing past landscapes from fossil pollen data: a review and results from the POLLANDCAL network. Veg. Hist. Archaeobot. 17, 419-443.

Gaillard, M.J., Sugita, S., Mazier, F., Trondman, A.K., Broström, A., Hickler, T., Kaplan, J.O., Kjellström, E., Kokfelt, U., Kunes, P., Lemmen, C., Miller, P., Olofsson, J., Poska, A., Rundgren, M., Smith, B., Strandberg, G., Fyfe, R., Nielsen, A.B., Alenius, T., Balakauskas, L., Barnekow, L., Birks, H.J.B., Bjune, A. Björkman, L., Giesecke, T., Hjelle, K., Kalnina, L., Kangur, M., van der Knaap, W. Koff, T., Lagerås, P., Latałowa, M., Leydet, M., Lechterbeck, J., Lindbladh, M., Odgaard, B.V., Peglar, S., Segerström, U., von Stedingk, H., Seppä, H., 2010. Holocene land-cover reconstructions for studies on land cover-climate feedbacks. Clim. Past 6, 483-499.

Giesecke, T., Fontana, S.L., 2008. Revisiting pollen accumulation rates from Swedish lake sediments. Holocene 18, 293-305.

Giesecke, T., Bennett, K.D., Birks, H.J.B., Bjune, A.E., Bozilova, E., Feurdean, A., Finsinger, W., Froyd, C., Pokorný, P., Rösch, M., Seppä, H., Tonkov, S., Valsecchi, V., Wolters, S., 2011. The pace of Holocene vegetation change testing for synchronous developments. Quat. Sci. Rev. 30, 2805-2814.

Giesecke, T., Davis, B., Brewer, S., Finsinger, W., Wolters, S., Blaauw, M., de Beaulieu, J.L., Binney, H., Fyfe, R.M., Gaillard, M.J., Gil-Romera, G., van der Knaap, W.O., Kunes, P., Kuhl, N., van Leeuwen, J.F.N., Leydet, M. Lotter, A.F., Ortu, E., Semmler, M., Bradshaw, R.H.W., 2014. Towards mapping the late Quaternary vegetation change of Europe. Veg. Hist. Archaeobot. 23, 75-86.

Grimm, E., 1987. CONISS: a FORTRAN 77 program for stratigraphically constrained cluster analysis by the method of incremental sum of squares. Comput. Geosci. $13,13-35$.

Grimm, E., Jacobson, G.L., 1992. Fossil-pollen evidence for abrupt climate changes during the past 18,000 years in eastern North America. Clim. Dyn. 6, 179-184.

Haas, J.N., Richoz, I., Tinner, W., Wick, L., 1998. Synchronous Holocene climatic oscillations recorded on the Swiss Plateau and at timberline in the Alps. Holocene 8, 301-309.

Haas, J.N., Giesecke, T., Karg, S., 2003. Die mitteleuropäische Subsistenzwirtschaft des 3. bis 2. Jahrtausends v. Chr. aus paläoökologischer Sicht. In: Müller, J. (Ed.), Vom Endneolithikum zur Frühbronzezeit: Muster sozialen Wandels? Tagung Bamberg, Bonn, pp. 21-28.

Heiri, O., Lotter, A.F., Hausmann, S., Kienast, F., 2003. A chironomid-based Holocene summer air temperature reconstruction from the Swiss Alps. Holocene 13, $477-484$.

Hellman, S., Gaillard, M.J., Broström, A., Sugita, S., 2008a. The REVEALS model, a new tool to estimate past regional plant abundance from pollen data in large lakes: validation in southern Sweden. J. Quat. Sci. 23, 21-42.

Hellman, S., Gaillard, M.J., Broström, A., Sugita, S., 2008b. Effects of the sampling design and selection of parameter values on pollen-based quantitative reconstructions of regional vegetation: a case study in southern Sweden using the REVEALS model. Veg. Hist. Archaeobot. 17, 445-459.

Hellman, S., Gaillard, M.J., Bunting, J.M., Mazier, F., 2009. Estimating the relevant source area of pollen in the past cultural landscapes of southern Sweden - a forward modelling approach. Rev. Palaeobot. Palynol. 153, 259-271.

Hicks, S., 2001. The use of annual arboreal pollen deposition values for delimiting tree-lines in the landscape and exploring models of pollen dispersal. Rev. Palaeobot. Palynol. 117, 1-29.

Hjelle, K., Sugita, S., 2012. Estimating pollen productivity and relevant source area of pollen using lake sediments in Norway: how does lake size variation affect the estimates? Holocene 22, 313-324.

Hormes, A., Müller, B.U., Schlüchter, C., 2001. The Alps with little ice: evidence for eight Holocene phases of reduced glacier extent in the Central Swiss Alps. Holocene 11, 255-265.

Imbrie, J., Boyle, E.A., Clemens, S.C., Duffy, A., Howard, W.R., Kukla, G., Kutzbach, J., Martinson, D.G., McIntyre, A., Mix, A.C., Molfino, B., Morley, J.J., Peterson, L.C., Pisias, N.G., Prell, W.L., Raymo, M.E., Shackleton, N.J., Toggweiler, J.R., 1992. On the structure and origin of major glaciation cycles 1 . Linear responses to Milankovitch forcing. Paleoceanography 7, 701-738.

Jacobson, G.L., Webb, T., Grimm, E.C., 1987. Patterns and rates of vegetation change during the deglaciation of eastern North America. In: Ruddiman, W.F. Wright, H.E. (Eds.), North America and Adjacent Oceans during the Last Deglaciation. Geological Society of America, Boulder, Colorado, pp. 277-288.

Janssen, C.R., 1981. On the reconstruction of past vegetation by pollen analysis: a review. In: Proceedings of the IVth International Palynological Conference, Lucknow (1976-1977), vol. 3, pp. 163-172. 
Kalis, A.J., Merkt, J., Wunderlich, J., 2003. Environmental changes during the Holocene climatic optimum in central Europe - human impact and natural causes. Quat. Sci. Rev. 22, 33-79.

Kaplan, J.O., Krumhardt, K.M., Zimmermann, N., 2009. The prehistoric and preindustrial deforestation of Europe. Quat. Sci. Rev. 28, 3016-3034.

Kaplan, J.O., Krumhardt, K.M., Ellis, E.C., Ruddiman, W.F., Lemmen, C., Goldewijk, K.K., 2011. Holocene carbon emissions as a result of anthropogenic land cover change. Holocene 21, 775-791.

Korhola, A., Vasko, K., Toivonen, H.T.T., Olander, H., 2002. Holocene temperature changes in northern Fennoscandia reconstructed from chironomids using Bayesian modelling. Quat. Sci. Rev. 21, 1841-1860.

Larocque, I., Hall, R.I., 2004. Holocene temperature estimates and chironomid community composition in the Abisko Valley, northern Sweden. Quat. Sci. Rev. 23, 2453-2465.

Lemmen, C., Wirtz, K.W., 2014. On the sensitivity of the simulated European Neolithic transition to climate extremes. J. Archaeol. Sci.. http://dx.doi.org 10.1016/j.jas.2012.10.023 (in press)

Lepš, J., Šmilauer, P., 2003. Multivariate Analysis of Ecological Data Using CANOCO. Cambridge University Press, Cambridge.

MacCune, B., Grace, J., 2002. Analysis of Ecological Communities. MjM Software, Gleneden Beach, Oregon, USA, p. 304.

Magurran, A.E., 2004. Measuring Biological Diversity. Blackwell Publishing, Oxford.

Marquer, L., 2012. Holocene REVEALS reconstructions of vegetation cover along N$\mathrm{S}$ and $\mathrm{W}-\mathrm{E}$ transects in North and Central Europe for evaluation of a dynamic vegetation model - the Swedish LANDCLIM project. Quat. Int. 279-280, 308.

Matthews, J.A., Dahl, S.O., Nesje, A., Berrisford, M.S., Andersson, C., 2000. Holocene glacier variations in central Jotunheimen, southern Norway based on dista glaciolacustrine sediment cores. Quat. Sci. Rev. 19, 1625-1647.

Matthias, I., Giesecke, T., 2014. Insights into pollen source area, transport and deposition from modern pollen accumulation rates in lake sediments. Quat. Sci. Rev. 87, 12-23.

Matthias, I., Nielsen, A.B., Giesecke, T., 2012. Evaluating the effect of flowering age and forest structure on pollen productivity estimates. Veg. Hist. Archaeobot. 21, $471-484$.

Mazier, F., Broström, A., Gaillard, M.J., Sugita, S., Vittoz, P., Buttler, A., 2008. Pollen productivity estimates and relevant source area of pollen for selected plant taxa in a pasture woodland landscape of the Jura Mountains (Switzerland). Veg. Hist. Archaeobot. 17, 479-495.

Mazier, F., Gaillard, M.J., Kuneš, P., Sugita, S., Trondman, A.K., Broström, A., 2012 a Testing the effect of site selection and parameter setting on REVEALS-mode estimates of plant abundance using the Czech Quaternary Palynological Database. Rev. Palaeobot. Palynol. 187, 38-49.

Mazier, F., Nielsen, A.B., Broström, A., Sugita, S., Hicks, S., 2012b. Signals of tree volume and temperature in a high-resolution record of pollen accumulation rates in northern Finland. J. Quat. Sci. 27, 564-574.

Mitchell, F.J.G., 2005. How open were European primeval forests? Hypothesis testing using palaeoecological data. J. Ecol. 93, 168-177.

Nesje, A., Jansen, E., Birks, H.J.B., Bjune, A.E., Bakke, J., Andersson, C., Dahl, S.O., Klitgaard-Kristensen, D., Lauritzen, S.E., Lie, Ø., Risebrobakken, B., Svendsen, J.I., 2005. Holocene climate variability in the Northern North Atlantic region: a review of terrestrial and marine evidence. In: Drange, H., Dokken, T., Furevik, T., Gerdes, R., Berger, W. (Eds.), The Nordic Seas: an Integrated Perspective Geophysical Monograph Series 158, pp. 289-322.

Nicolussi, K., Patzelt, G., 2000. Discovery of early Holocene wood and peat on the forefield of the Pasterze Glacier, Eastern Alps, Austria. Holocene 10, 191-199.

Nielsen, A.B., 2004. Modelling pollen sedimentation in Danish lakes at c. A.D. 1800 an attempt to validate the POLLSCAPE model. J. Biogeogr. 31, 1693-1709.

Nielsen, A., Odgaard, B., 2010. Quantitative landscape dynamics in Denmark through the last three millennia based on the Landscape Reconstruction Algorithm approach. Veg. Hist. Archaeobot. 19, 375-387.

Nielsen, A.B., Sugita, S., 2005. Estimating relevant source area of pollen for small Danish lakes around AD 1800. Holocene 15, 1006-1020.

Nielsen, A.B., Giesecke, T., Theuerkauf, M., Feeser, I., Behre, K.E., Beug, H.J., Chen, S.H. Christiansen, J., Dörfler, W., Endtmann, E., Jahns, S., de Klerk, P., Kühl, N. Latałowa, M., Odgaard, B.V., Rasmussen, P., Stockholm, J.R., Voigt, R. Wiethold, J., Wolters, S., 2012. Quantitative reconstructions of changes in regional openness in north-central Europe reveal new insights into old questions. Quat. Sci. Rev. 47, 131-149.

Odgaard, B.V., 1994. The Holocene vegetation history of northern West Jutland. Opera Bot. 123, 1-171.

Odgaard, B.V., 1999. Fossil pollen as a record of past biodiversity. J. Biogeogr. 26, $7-$

Odgaard, B.V., 2001. Palaeoecological perspectives on pattern and process in plant diversity and distribution adjustments: a comment on recent developments. Divers. Distrib. 7, 197-201.

Odgaard, B.V., 2007. Reconstructing past biodiversity. In: Elias, S.A. (Ed.), Encyclopedia of Quaternary Science. Elsevier, Amsterdam, pp. 2508-2514.

Olsson, F., Lemdahl, G., 2009. A continuous Holocene beetle record from the site Stavsåkra, southern Sweden: implications for the last 10600 years of forest and land use history. J. Quat. Sci. 24, 612-626.

Olsson, F., Lemdahl, G., 2010. A forest history for the last 10900 years at the site Storasjö, southern Sweden: implications from beetle assemblages. J. Quat. Sci. $25,1211-1221$

Poska, A., Meltsov, V., Sugita, S., Vassiljev, J., 2011. Relative pollen productivity estimates of major anemophilous taxa and relevant source area of pollen in cultural landscape of the hemi-boreal forest zone (Estonia). Rev. Palaeobot. Palynol. 167, 30-39.

Prentice, I.C., 1980. Multidimensional scaling as a research tool in Quaternary palynology: a review of theory and methods. Rev. Palaeobot. Palynol. 31, 71104.

Prentice, I.C., 1988. Records of vegetation in time and space: the principles of pollen analysis. In: Huntley, B., Webb, T. (Eds.), Vegetation History. Springer, Dordrecht, pp. 17-42.

Prentice, I.C., Cramer, W., Harrison, S.P., Leemans, R., Monserud, R.A., Solomon, A.M. 1992. A global biome model based on plant physiology and dominance, soil properties and climate. J. Biogeogr. 19, 117-134.

Prentice, I.C., Harrison, S.P., Jolly, D., Guiot, J., 1998. The climate and biomes of Europe at 6000 yr BP: comparison of model simulations and pollen-based reconstructions. Quat. Sci. Rev. 17, 659-668.

Räsänen, S., Suutari, H., Nielsen, A.B., 2007. A step further towards quantitative reconstruction of past vegetation in Fennoscandian boreal forests: pollen productivity estimates for six dominant taxa. Rev. Palaeobot. Palynol. 146, 208220.

Renssen, H., Seppä, H., Heiri, O., Roche, D.M., Goosse, H., Fichefet, T., 2009. The spatial and temporal complexity of the Holocene thermal maximum. Nat. Geosci. 2, 411-414.

Rosenzweig, M.L., 1995. Species Diversity in Space and Time. Cambridge University Press, Cambridge.

Ruddiman, W.F., 2003. The anthropogenic greenhouse era began thousands of years ago. Clim. Change 61, 261-293.

Ruddiman, W.F., Kutzbach, J.E., Vavrus, S.J., 2011. Can natural or anthropogenic explanations of late-Holocene $\mathrm{CO}_{2}$ and $\mathrm{CH}_{4}$ increases be falsified? Holocene 21, 865-879.

Seppä, H., Nyman, M., Korhola, A., Weckström, J., 2002. Changes of treelines and alpine vegetation in relation to post-glacial climate dynamics in northern Fennoscandia based on pollen and chironomid records. J. Quat. Sci. 17, 287-301.

Seppä, H., Alenius, T., Muukkonen, P., Giesecke, T., Miller, P.A., Ojala, A.E.K., 2009. Calibrated pollen accumulation rates as a basis for quantitative tree biomass reconstructions. Holocene 19, 209-220.

Shennan, S., 2009. Evolutionary demography and the population history of the European early Neolithic. Hum. Biol. 81. Article 12. Available at: http:// digitalcommons.wayne.edu/humbiol/vol81/iss2/12.

Soepboer, W., Sugita, S., Lotter, A.F., van Leeuwen, J.F.N., van der Knaap, W.O., 2007. Pollen productivity estimates for quantitative reconstruction of vegetation cover on the Swiss Plateau. Holocene 17, 65-77.

Soepboer, W., Sugita, S., Lotter, A.F., 2010. Regional vegetation-cover changes on the Swiss Plateau during the past two millennia: a pollen-based reconstruction using the REVEALS model. Quat. Sci. Rev. 29, 472-483.

von Stedingk, H., Fyfe, R., Allard, A., 2008. Pollen productivity estimates from the forest-tundra ecotone in west-central Sweden: implications for vegetation reconstruction at the limits of the boreal forest. Holocene 18, 323-332.

Sugita, S., 1993. A model of pollen source area for an entire lake surface. Quat. Res. 39, 239-244.

Sugita, S., 1994. Pollen representation of vegetation in Quaternary sediments: theory and method in patchy vegetation. J. Ecol. 82, 881-897.

Sugita, S., 1998. Modelling pollen representation of vegetation. In: Gaillard, M.J., Berglund, B.E., Frenzel, B., Huckriede, U. (Eds.), Quantification of Land Surfaces Cleared of Forests During the Holocene, Palaeoklimaforschung/Palaeoclimate Research 27. Gustav Fisher Verlag Stuttgart, pp 125-132.

Sugita, S., 2007a. Theory of quantitative reconstruction of vegetation I: pollen from large sites REVEALS regional vegetation composition. Holocene 17, 229-241.

Sugita, S., 2007b. Theory of quantitative reconstruction of vegetation II: all you need is LOVE. Holocene 17, 243-257.

Sugita, S., 2013. POLLSCAPE Model: simulation approach for pollen representation of vegetation and land cover. In: Elias, S.A., Mock, C.J. (Eds.), Encyclopedia of Quaternary Science, second ed., vol. 3. Elsevier, Amsterdam, pp. $871-879$

Sugita, S., Gaillard, M.J., Broström, A., 1999. Landscape openness and pollen records: a simulation approach. Holocene 9, 409-421.

Sugita, S., Gaillard, M.J., Hellman, S., Broström, A., 2008. Model-based reconstruction of vegetation and landscape using fossil pollen. In: Proceedings of the CAA (Computer Applications and Quantitative Methods in Archaeology), Berlin, Germany, pp. 1-6.

Sugita, S., Hicks, S., Sormunen, H., 2010. Absolute pollen productivity and pollen vegetation relationships in northern Finland. J. Quat. Sci. 25, 724-736.

Svenning, J.C., 2002. A review of natural vegetation openness in north-western Europe. Biol. Conserv. 104, 133-148.

Tarasov, P., Williams, J.W., Andreev, A., Nakagawa, T., Bezrukova, E., Herzschuh, U., Igarashi, Y., Müller, S., Werner, K., Zheng, Z., 2007. Satellite- and pollen-based quantitative woody cover reconstructions for northern Asia: verification and application to late-Quaternary pollen data. Earth Planet. Sci. Lett. 264, 284298.

Velle, G., Brooks, S.J., Birks, H.J.B., Willassen, E., 2005. Chironomids as a tool for inferring Holocene climate: an assessment based on six sites in southern Scandinavia. Quat. Sci. Rev. 24, 1429-1462.

Vellend, M., 2001. Do commonly used indices of $\beta$-diversity measure species turnover? J. Veg. Sci. 12, 545-552.

Vera, F., 2000. Grazing Ecology and Forest History. CABI Publishing, New York, United States. 
Wang, Y., Herzschuh, U., 2011. Reassessment of Holocene vegetation change on the upper Tibetan Plateau using the pollen-based REVEALS model. Rev. Palaeobot. Palynol. 168, 31-40.

Whitehouse, N.J., Smith, D.N., 2004. 'Islands' in Holocene forests: implications for forest openness, landscape clearance and 'Culture-Steppe' species. Environ. Archaeol. 9, 199-208.

Williams, J.W., 2002. Variations in tree cover in North America since the last glacial maximum. Glob. Planet. Change 35, 1-23.
Williams, J.W., Tarasov, P., Brewer, S., Notaro, M., 2011. Late Quaternary variations in tree cover at the northern forest-tundra ecotone. J. Geophys. Res. 116, G01017. http://dx.doi.org/10.1029/2010JG001458.

Woodbridge, J., Fyfe, R.M., Roberts, N., Downey, S., Edinborough, K., Shennan, S. 2014. The impact of the Neolithic agricultural transition in Britain: a comparison of pollen-based land-cover and archaeological ${ }^{14} \mathrm{C}$ date-inferred population change. J. Archaeol. Sci.. http://dx.doi.org/10.1016/j.jas.2012.10.025 (in press). 